DePauw University

Scholarly and Creative Work from DePauw University

Sociology \& Anthropology Faculty publications

Sociology \& Anthropology

$12-15-2018$

\title{
Maroon Archaeology Beyond the Americas: A View From Kenya
}

Lydia Wilson Marshall

DePauw University, lydiamarshall@depauw.edu

Follow this and additional works at: https://scholarship.depauw.edu/socanth_facpubs

Part of the Archaeological Anthropology Commons

\section{Recommended Citation}

This is a post-peer-review, pre-copyedit version of an article published in Historical Archaeology. The final authenticated version is available online at: https://doi.org/10.1007/s41636-018-0146-3

This Article is brought to you for free and open access by the Sociology \& Anthropology at Scholarly and Creative Work from DePauw University. It has been accepted for inclusion in Sociology \& Anthropology Faculty publications by an authorized administrator of Scholarly and Creative Work from DePauw University. 
Author:

Work Address: Department of Sociology and Anthropology

Asbury Hall 118

DePauw University

P.O. Box 37

Greencastle, IN 46135-0037

Work Phone:

Cell Phone:

Email Address: $\quad$ lydiamarshall@ depauw.edu
765-658-4508

$765-655-4344$ 
Lydia Wilson Marshall

Maroon Archaeology beyond the Americas: A View from Kenya

\begin{abstract}
Archaeological research on Maroons - that is, runaway slaves - has been largely confined to the Americas. This essay advocates a more global approach. It specifically uses two runaway slave communities in $19^{\text {th }}$-century coastal Kenya to rethink prominent interpretive themes in the field, including “Africanisms," Maroons' connections to indigenous groups, and Maroon group cohesion and identity. This article's analysis demonstrates that the comparisons enabled by a more globalized perspective benefit the field. Instead of eliding historical and cultural context, these comparisons support the development of more localized and historically specific understandings of individual runaway slave communities both in Kenya and throughout the New World.
\end{abstract}


Introduction

In recent decades, historical archaeology has become an increasingly global field. In the past few years alone, the journal Historical Archaeology has published research on South Asia (e.g., Wilson and Hauser 2016), Western Asia (e.g., Brooks and Young 2016), Latin America (e.g., Funari, and Ferreira 2016), Northern Europe (e.g., Symonds et al. 2015), Australia (e.g., Davies 2013), and Africa (e.g., Posnansky 2013). With the field's continuing globalization, its edges have become fuzzier, its agendas more diverse, and its coherence sometimes less clear. We have also gained a much richer diversity of interpretive approaches and tools. This article specifically considers how a more global orientation may benefit Maroon archaeology, which studies runaway slaves. Maroon archaeology is a vibrant, though still comparatively young, field. Since the 1980s, archaeologists have studied an increasingly diverse range of Maroon sites (Weik 2012) — from large and socially complex polities like Brazil's Palmares (Funari 2003) to small and more transient encampments like those in the Great Dismal Swamp of North Carolina and Virginia (Sayers 2014). While Maroon archaeology's geographic scope continues to widen, nearly all investigated sites are still located somewhere in the New World (cf. Chowdhury 2015, Mapunda 2017). Here, I want us to consider what the field stands to gain from the study of Maroons outside of the Americas.

My particular focus is two runaway slave settlements in 19th-century Kenya, Koromio and Makoroboi, which were excavated in 2007-2008. I want us to consider how existing interpretive themes in Maroon archaeology change when we extend the geographic frame. How does our understanding of "Africanisms" shift, for example, when analyzing cases of slavery and self-emancipation within Africa? How were relationships with nearby indigenous groups different when Maroons were not physically distinguishable from their neighbors? This article 
reviews the state of Maroon archaeology in the Americas; I then use my research on runaway slave settlements in Kenya to both destabilize and enrich the established interpretive framework of the field.

Maroon Archaeology in the Americas

In Maroon studies, archaeology is still often viewed as a poor cousin to longerestablished historical and ethnographic approaches (Agorsah 2007a:351). Yet, despite many Maroon scholars' skepticism, archaeology's material data and distinctive methodology offer unique interpretive benefits. The field's potential is most clear when compared to documentary analysis. Colonial descriptions of Maroons tend to homogenize and demean them as "fugitive negroes" (Weik 2005:37). Archaeological analysis of Maroon communities helps to complicate and challenge these "master narratives of power" (Orser and Funari 2001:64; see also Allen 2001:81; Funari 2007:360).

Historical archaeologists often grapple with the misrepresentation of their subjects in documents; the problem of such bias, however, must be considered "especially serious in cases where men and women being written about were commonly referred to as 'criminals' and 'outlaws"” (Orser and Funari 2001:64). Many historical descriptions of Maroon communities were penned by soldiers who had participated in military campaigns against them; these accounts pay little attention to the settlements' physical environments (Agorsah 2006a:195) and less to their sociocultural organization (Funari 1995:14). Other descriptions of Maroons were written by colonists with only second- or third-hand knowledge; skepticism about their conclusions is thus crucial. Historical records also tend to emphasize Maroons' relationships with colonial groups; these documents offer much less insight into Maroons' ties to Native Americans - ties that 
archaeologists have increasingly recognized as vital to understanding such self-emancipated communities (Weik 2005:40).

The advantages of an archaeological approach to Maroons over an ethnographic approach are less immediately obvious but equally important. In some New World areas, such as Jamaica (e.g., Bilby 2005) and Suriname (e.g., Price 1983), Maroon descendant communities have been the focus of intense ethnographic scrutiny. Yet, in studying living Maroon societies, ethnographers only observe the cultural end product of a sometimes centuries-long process of community creation. Archaeology permits a more thorough examination of the formation and transformation of these groups (Agorsah 2006b:175). Thus, while ethnographers grapple with the "flesh" of descendant Maroon societies - that is, their cultural practices and traditionsarchaeologists search for these groups' "skeletons"- their concealed historical cores (Agorsah 2007b:561, see also Weik 2012:48-49; White 2015:251).

Maroon archaeology remains a decidedly young field. While some Latin American countries have a longer history of research (e.g., Vega 1979), most archaeological studies of Maroons date only to the last 30 years. The Great Dismal Swamp of North Carolina and Virginia was first surveyed for Maroon encampments in the late 1980s (Nichols 1988); Nanny Town and Accompong, both well-known refuges in Jamaica, attracted sustained archaeological attention in 1991 (Agorsah 1993:185, 1994:164); in 1992, excavators broke ground at Brazil's Palmares, once the most populous Maroon settlement in the Americas (Orser 1992; Allen 1998:148); and an international team began large-scale regional survey to locate Surinamese Maroon villages in 1996 (Agorsah 2006a:191). Despite the field's impressive growth, practitioners of Maroon archaeology are still few and the number of sites they have investigated remains small. Maroons' under-representation in archaeological research is all the more striking when one considers how 
widespread marronage was in the Americas, with known historical examples in Mexico, the Bahamas, Cuba, the Dominican Republic, Haiti, Jamaica, French Guiana, Brazil, Columbia, Suriname, Panama, Belize, Antigua, Guadeloupe, Honduras, St. Vincent, St. Lucia, St. Thomas, St. Kitts, St. John, Martinique, Grenada, and the United States (Agorsah 1995:225, Sayers 2012:137).

Early research was often wholly atheoretical; archaeologists limited themselves to modest methodological goals such as site identification and survey (Weik 1997:83) and struggled to find meaningful interpretive footholds for Maroon material culture (Orser 1998:72). While recent studies are typically more theoretically ambitious, their foci remain diverse. In 2007, E. Kofi Agorsah (2007b:555) lamented Maroon archaeology's continued lack of a shared "theoretical and methodological basis of interpretation." In 2015, Cheryl White (2015:257) echoed Agorsah's concerns, noting that the relative dearth of Maroon research has impeded the creation of "a coherent idiom, frame of reference, and reliable set of research tools for regional comparison." Despite the field's prolonged growing pains, distinct interpretive themes have emerged, including African cultural continuities, the relationship between Maroons and Native Americans, and the development of Maroon identities. Given Maroon archaeology's growing vigor and interpretive coherence, what might be gained from considering refugees from slavery outside of the Americas? Is there value in widening the geographic scope? Or is it, in fact, counterproductive to undermine the field's nascent coherence by loosening the geographic frame? Should we simply accept that some sub-fields of historical archaeology might be reasonably delimited to specific regions? This article argues that Maroon archaeology benefits from a widened geographic outlook. Specifically, a more global perspective provides an opportunity to rethink and refine established research themes in the field. 
Maroon Archaeology in Kenya

This study aligns with growing efforts to broaden our understanding of the African Diaspora beyond the Atlantic. Jonathan Walz and Steven Brandt (2006) have especially urged archaeologists to pay more attention to Africans' dispersal and displacement in the Indian Ocean region, including coastal Eastern Africa where Koromio and Makoroboi are located. Even in the Americas, Maroon archaeological research has tended to be patchy in its geographical distribution (Weik 2012:79). In the Indian Ocean area, such research remains almost nonexistent. The island nation Mauritius maintains the region's best established archaeological program on escaped slaves (e.g., Chowdhury 2015). A study in Tanzania also recently used archaeological data to argue for the fugitive slave origins of the Matumbi ethnic group there (Mapunda 2017). However, archaeologists have not yet studied Maroons throughout most of the Indian Ocean region, even in places like Madagascar and India where historians have convincingly demonstrated that African captives practiced marronage (e.g., Alpers 2003:61, Guha 2006:181). Historical archaeology in many parts of the Indian Ocean region is still in its infancy (Walz and Brandt 2006:250). Much work remains to be done. Research on marronage in the Indian Ocean world promises to enable within- and between-region comparisons of captives' experiences of displacement and strategies of marronage.

"Maroon" is a term with deep historical roots in the Americas. The Spanish cimaroon initially referred to runaway cattle in Hispaniola; but, by the 1530s, it had developed into a term for runaway slaves (Price 1973:1-2). Refugees from slavery in Kenya, conversely, never referred to themselves as Maroons. Indeed, this term was not in use at all in $19^{\text {th }}$-century Eastern Africa. I realize this section's title ("Maroon archaeology in Kenya") thus may seem a little 
geographically muddled. Yet, however provincial its etymology may be, Maroon archaeology has much to gain from a more global orientation.

The Swahili Coast is an Eastern African corridor that runs from approximately Mogadishu, Somalia to, in its southern reaches, coastal Mozambique (Figure 1). For at least 2,000 years, this coastal region acted an important center for the trade of enslaved peoples and other commodities in the Indian Ocean commercial network. The slave trade on the Swahili Coast is first mentioned in Greek documents dating to the second century A.D. (Beachey 1976a:3). In the $19^{\text {th }}$ century, the Omani Sultanate controlled much of this coast. In 1840 , the Sultanate relocated the seat of its empire from Muscat, Oman to Zanzibar, a major offshore island of the Swahili Coast that is now part of Tanzania. On the coast, both Omani colonists and Swahili indigenes used slave labor in a burgeoning plantation system to grow grain, coconuts, and cloves (Cooper 1977:181, Croucher 2015:41-46). Enslaved people came from a diversity of areas, but many captives originated in the Lake Nyasa (Lake Malawi) region, about $700 \mathrm{~km}$ southwest of Zanzibar (Beech 1916:146; Beachey 1976b:65; Sheriff 1985:170). Indeed even today, Mnyasa (person of the Lake Nyasa region, Swahili, sing.) is understood as an epithet and may be used interchangeably with mtumwa (slave, Swahili, sing.) to refer to individuals of suspected slave ancestry. The enslaved were captured through a variety of means. Some were caught up in raids organized by outsiders, others were sold to settle debts, and some were turned over to caravans when suspected of witchcraft (e.g., Livingstone and Livingstone1865:125, 381; Alpers 1997).

Once captives reached the coast, slavers and slave owners treated them as nonpersons. Common derisive terms for recently enslaved workers, such as waja (newcomers, Swahili, pl.) and watumwa wajinga (ignorant slaves, Swahili, pl.), emphasized their status as outsiders in 
coastal society. Both Omani and Swahili slave owners also denigrated the enslaved in religious terms. Unbelief was a classic rationalization of slavery on the coast. Slaveholders often attributed enslaved peoples' servitude to their unwillingness or that of their forebears to adopt Islam. Within this religious framework, slave owners legitimized slavery as the spiritual liberation of slaves from heathenism. While slaveholders encouraged captives' conversion, they also emphasized slaves' inferior Muslim piety. Slave owners reinforced their own sense of greater religious purity by barring enslaved people from participating in certain religious functions, forbidding both male and female slaves from covering their heads, and restricting enslaved peoples' use of Koranic names (Cooper 1981:271- 307). Toward the end of the 19th century, slave owners also demeaned enslaved workers in racialized terms. As Omani colonists' local authority strengthened, coastal elites of both Arab and African descent more consistently characterized enslaved peoples' inferiority as a black inferiority. That is, captives' blackness rather than their non-Muslim status increasingly marked them as enslaveable (Cooper 1977:267; Morton 1990:3-5). Swahili patricians also began to more strongly emphasize their own (constructed or partial) foreign ancestry, which provided darker-skinned elites with a racial means of distinguishing themselves from enslaved people (Glassman 1995:92).

Slave owners on the Swahili Coast relied on geographic, cultural, and social isolation as tools of enslavement. By procuring captives from distant homelands, Swahili and Omani elites ensured that those they enslaved would be geographically and culturally disoriented on the coast. Constant denigration of captives as non-persons or "brute beasts" (Taylor 1891:78) relegated new arrivals to the lowest rung of Swahili society. To symbolically sever any lingering connection to their natal homelands, newly enslaved people were often renamed and re-clothed by their owners upon their arrival to the coast (Prestholdt 2008:122). A significant means by 
which captives resisted the isolation of enslavement was by building bonds with one another, both in slavery and in self-liberation. Several independent runaway slave settlements developed from these alliances. The development of self-liberated communities is also linked to deteriorating working conditions for enslaved people in the mid-19 $9^{\text {th }}$ century. Then, British naval and political pressure curtailed Oman's overseas export of enslaved captives; mounting restrictions on slave export markets in turn encouraged the development and consolidation of a local plantation system that exploited enslaved labor to produce cash crops for "legitimate" trade (Glassman 1995:81; Sheriff 1985:169, 1987:60).

In Swahili, fugitive slaves were known as watoro; watoro translates simply as “runaways" (Cooper 1977, 205). I excavated two watoro settlements in 2007-2008, Koromio and Makoroboi; these were both inhabited by refugees from slavery in the hinterland of what is now coastal Kenya (Figure 2). These sites were identified first through written historical documentation, in addition to, later, oral history and archaeological survey (Marshall 2011:86100, 401-407). The settlements differed in their decade of inhabitation and in their population. Koromio was occupied in the 1840s and Makoroboi in the 1880s. At its height, Makoroboi approached 700 inhabitants (Handford 1885:167) and Koromio was only ever a fraction of that size. They also varied in their position in regional social and economic networks: Makoroboi maintained close connections to British missionaries (e.g., Price 1882) while Koromio served as a regional hub for the trade of ivory and cattle (Krapf 1846a; Morton 1978). But both had relatively short occupations, likely less than 10 years, and were abruptly abandoned after being razed and burned in attacks by slave owners (Handford 1885:167; Krapf 2002:90). Evidence for unplanned abandonment and fiery destruction are among the most telling material signatures at both sites, where burned preserved wattle-and-daub house walls were accompanied by complete 
pots broken in place and sitting right side up on what was once the ground surface. At Koromio, I additionally recovered carbonized food stuffs alongside whole broken pots in an abandoned cooking area just outside of a collapsed, burned wattle-and-daub structure. In some ways, these settlements mirror what is known of Maroon life in the Americas - for example, in the sustained (and eventually realized) threat that residents faced from slave owners. In other ways, however, Koromio and Makoroboi depart from typical Americanist understanding of Maroons-for example, in the near-total integration of their inhabitants into neighboring indigenous communities. This article reviews three prominent and interrelated interpretive themes in Maroon archaeology; I then consider how Koromio and Makoroboi may both complicate and refine archaeologists' understanding and application of these themes.

\section{"Africanisms" and Cultural Persistence}

So-called "Africanisms" (that is, cultural practices retained from Africa) have long been a mainstay of research in Maroon archaeology and African American archaeology more broadly. Academic disputes over how much culture enslaved Africans retained from the continent are longstanding, dating at least to the Frazier-Herskovits debate in the mid-20th century. The sociologist E. Franklin Frazier (1949) argued the Middle Passage was too traumatic and disruptive to permit the preservation of African cultural traditions; displaced Africans and their descendants, he contended, forged new sociocultural forms in enslavement fashioned after the European American models near at hand. Melville Herskovits (1941) argued against the idea that African culture had been obliterated through the slave system; the anthropologist worked to identify "Africanisms"- that is, cultural traits that captives and their descendants retained from their African motherlands in the New World. Evoking African culture as unchanging, 
homogeneous, and portable (Allen 1998:157; White 2015:254), the concept of "Africanisms" as originally conceived by Herskovits is undoubtedly simplistic. Yet, archaeologists have produced increasingly sophisticated analyses of the role of African heritage in African American cultural creation. Archaeologists' investigations of African cultural influences in slave contexts have encompassed diet (e.g., Otto 1984), house style and domestic spatial organization (e.g., Ferguson 1992; Armstrong 2011), and religion and ideology (e.g., Samford 1999; Fennell 2007).

In seeking these cultural connections to the continent, we must also remember that enslaved people had limited control over how they ordered their lives; these restrictions are relevant to the archaeological interpretation of slave-related contexts. For example, since slave owners often dictated the form and arrangement of slave houses, archaeological analyses of these structures may offer more insight into European American strategies of subjugation than into African American cultural creation. Of course, archaeologists have used other data, like ritual deposits and praise houses, to document African American cultural creation and African cultural persistence within plantation settings (e.g., Brown 2015). Nonetheless, Maroons maintained a much greater degree of control over their daily lives than enslaved people even taking into account colonial recapture efforts. Thus, Maroon house styles, domestic spatial arrangements, and activity areas provide archaeologists with direct insight into lifeways more freely created by Africans in the Diaspora (Weik 2005:43). Due to these advantages, much early Maroon research attempted to identify runaways' retention or revival of culture traditions from Africa (Ogundiran and Falola 2007:34; Fellows and Delle 2015:119-120).

Researchers have examined Maroons' connections to the continent through diverse data. A few sites have yielded artifacts of African provenience. Harvested from the Indian Ocean, cowry shells served as a kind of currency in much of West Africa during the slave trade era. 
Cowry shells unearthed in Maroon settlements in Jamaica (Agorsah 1993:190) and Suriname (White 2010:475) provide a direct physical connection to Africa and were likely carried from the continent by captives or slavers. Researchers have also considered African influences on Maroon material cultural style, linking, for example, geometrically incised pipe decoration in West African and Maroon contexts (Weik 2004:35).

Archaeologists have additionally used their material data to investigate parallel cultural practices. Faunal evidence in Cuba suggests Maroons there maintained a diverse diet including dogs and horses in addition to the pigs, chickens, cows, and ducks more typically found on Cuban historic sites. Gabino La Rosa Corzo (2005:176-177) argues that, rather than indicating only economic necessity, Maroons' consumption of dogs and horses relates to similar and contemporary culinary traditions in West Africa - for example, among the Yoruba and Ewe. For the Yoruba, at least, consumption of such animals was sometimes linked to ritual practice (La Rosa Corzo 2005:177). Faunal evidence on Cuban Maroon sites has additionally suggested that meat was not roasted, since large bones offer no evidence of burning. Instead, La Rosa Corzo (2005:171) maintains, the abundance of ceramic bowls found in hearth areas may be indicative of a soup-based cooking tradition with African roots.

Spatial analyses have been similarly critical in understanding Maroons' cultural connections to their African homelands. E. Kofi Agorsah (1999:48-49) has argued that the presumably family-based settlement pattern evident at Jamaican Maroon sites (with several structures placed around a shared yard space) mimics the spatial aggregation of familial houses often seen in West Africa. Agorsah also points out that some of the "cultural baggage" that Africans carried with them from their motherlands may be only indirectly visible. For example, Maroon survival strategies (such as mobility and defensive architecture) likely derived from 
those previously adopted by raided groups attempting to avoid capture and enslavement in Africa (Agorsah 1994:185; for examples, see Diouf 2003).

In recent decades, archaeologists have employed the concept of "Africanisms" with increasing theoretical sophistication and care (cf. White 2015:251) - considering in what ways enslaved people may have been restricted in the act of cultural creation, recognizing the diversity of practices and ideas that captives carried from the continent, and acknowledging Africa as encompassing many homelands rather than as a single static cultural origin point. My analysis of runaway slaves in 19th-century Kenya undergirds these theoretical developments_-particularly the interpretive emphasis on Africa's cultural diversity. The Kenyan case study also clearly demonstrates that the cultural mores and practices that runaways took with them into freedom were not just carried from their natal homelands but also developed under enslavement.

At Koromio, residents' diverse origins were materially marked. Though some enslaved workers were born on the Swahili Coast, many were captured from a variety of inland and hinterland homelands, including — but certainly not limited to - the Lake Nyasa region (Alpers 1967:5; Cooper 1977:120). Given the cultural heterogeneity of the slave population at large, runaways were likely similarly diverse. There is certainly no evidence in Kenya for runaway slave villages organized by ethnic origin as apparently occurred farther north in Somalia's Jubba River Valley; there, historical reports suggest that thousands of runaways settled into (at least somewhat) ethically segregated villages after escaping their Somali enslavers (Cassanelli 1987:222). In Kenya, Koromio residents' cultural heterogeneity is reflected in the site's archaeological patterns, most clearly in the inter-household distribution of imported glass beads. The cattle market at Koromio (Krapf 1846a) supported the consumption of a variety of imported items; imported ceramics, for example, were recovered in abundance at the site, with 753 sherds 
identified. More interpretively important for us here, however, is the site's assemblage of 75 imported European glass beads.

Each of the three wattle-and-daub structures excavated at Koromio yielded a distinctive European glass bead assemblage. At Structure 1, drawn white specimens constituted more than half the 41 glass bead assemblage (Table 1). Structure 2's 28-bead assemblage was unique in the comparative popularity of a medium bright blue drawn type, as well as the presence of a turquoise-on-white compound bead found nowhere else at the site (Table 2). While few beads were recovered at Structure 3, the small assemblage there was nonetheless distinct, with two wound blue and one wound white so-called pigeon egg beads representing three of the six ornaments recovered (Table 3).

It is particularly important to note that different inexpensive and less popular varieties of glass beads (Burton 1860:530-531) were recovered at each structure (Marshall 2011:288), showing that residents' choices were not simply dictated by differences in household wealth. Rather, the bead assemblages' dissimilarity suggests that residents at each structure chose to consume different bead types. Though men in 19th-century Eastern Africa might occasionally wear beads, such ornaments were much more closely culturally tied to women (e.g., Gissing 1884:556; Barrett 1911:30; Roberston 1997:31-32). As is true elsewhere in the world, adorning oneself with beads in Eastern Africa was never simply an act of beautification. Rather, such ornamentation was just as much about demonstrating social acceptability and marking cultural identity as it was about aesthetics (Labelle 2005: 17). Given the social and cultural functions of beads, it is unsurprising that $19^{\text {th }}$-century Eastern Africans were discriminating consumers of them. The popularity of different imported varieties varied season to season and settlement to settlement, much to the consternation of European explorers who were ill able to predict which 
bead types would be valued by their trading partners in the coastal hinterland and interior (e.g., Thomson 1881:35, see also Prestholdt 2008:63-65). Explorers Richard Burton and John Speke, for example, were forced to throw away several hundred strands of beads that interior groups in Eastern Africa had refused to accept in trade (Stanley 1872:24).

Given beads' importance in expressing linked gendered and cultural identities in the region (Marshall 2012a), Koromio households' differing consumption choices may reflect variant ideals of female adornment and beauty. Women enslaved on the Swahili Coast typically had fewer opportunities than men for religious education and participation in public cultural and economic life. Historian Thaddeus Sunseri (1993:485) has argued that these distinctions in treatment led enslaved women to remain more disengaged from Swahili culture than their male counterparts. Thus, female slaves' gender identities may have been rooted not so much in Swahili culture as in the norms of their varied origin communities. Previously enslaved women living at Koromio, therefore, may have had a range of conceptions of beauty and adornment to draw upon when buying and wearing beads.

Yet, what is equally apparent—both at Koromio and Makoroboi—is these villages' internal cultural coherence and distinctiveness from neighboring indigenous communities. Both watoro sites show strong evidence of Swahili cultural norms and practices, reflecting their residents' prior enslavement on the coast. Housing design, pottery style, and food preferences all point to a Swahili cultural orientation that is distinct from that of their free hinterland neighbors. For one, residents at both settlements lived in rectilinear wattle-and-daub houses; burned house remains clearly indicate earthen construction, and carbonized preserved house post stubs point to rectilinear shape (e.g., Figure 3; Marshall 2012b:370). Earthen house construction was unusual for hinterland communities in 19th-century Kenya (Anderson 1977:33-42); most groups instead 
made grass-thatched structures. Even more striking is these houses' shape. Rectilinear (rather than round) houses were almost unheard of inland of the Swahili Coast before the turn of the 20th century (McKim 1985:66-71).

Koromio and Makoroboi residents' replication of slave owners' house style departs from patterns of cultural rejection seen at some Maroon sites in the Americas. In analyzing the layout of the Black Seminole settlement Pilaklikaha, Terrance Weik (2012:132-133) surmised, "Unless they were deeply indoctrinated with a dependency mindset, it seems likely that they would have used their freedom to explore some settlement layout that did not remind them of their enslavement." Yet, watoro's broad-based acceptance of Swahili cultural norms, including house design, aligns with local understandings of slave resistance as rooted in efforts to participate more fully in the cultural, social, economic, and political life of slaveholder society (Glassman 1991, 1995; Prestholdt 2008; Croucher 2015; cf. Morton 1990:205). These efforts toward greater inclusion in Swahili life resisted the dehumanization and social isolation of enslavement. Runaways clearly refused their assigned social role as kinless non-persons even when they did not reject the larger Swahili cultural framework that underlay the logic of enslavement.

At Koromio, a complete Swahili-style ceramic lid was recovered broken in place in a preserved cooking activity area located to the northwest of Structure 1 (Figure 4). The lid's form is unique in its strongly upturned rim and round central handle. Similar lids have been recovered elsewhere in coastal Eastern Africa (e.g., Kirkman 1974:83; Croucher 2006:448-450), and modern potters on the coast continue to produce variations of them today (Croucher 2006:290). These lids are used to dry cooked food (typically rice) placed under the vessel; charcoal is piled in the crevice created by the upturned rim to heat the lid and draw excess water from the food underneath. The strongly upturned rim, which is diagnostic for this unique coastal-style vessel 
shape, was also identified at the two other structures excavated at Koromio, suggesting widespread rice consumption at the settlement. Archaeobotanical evidence also points to rice: More than 300 preserved grains of rice were recovered in association with Structure 2. Rice is a quintessentially coastal food, central to Swahili identity, and would have had to be imported to Koromio. Rice consumption at the settlement thus reflects not only trade connections to the coast but also continued observance of certain coastal dietary practices and norms.

The 71 lid sherds recovered at Koromio account for $12.4 \%$ of the 570 local ceramic sherds that were diagnostic for vessel shape; by weight, the lid sherds account for $10.6 \%$ of the local pottery assemblage for which vessel shape could be determined. If we subsume these lid sherds into the larger local ceramic assemblage of 12,764 pieces (including non-diagnostic body sherds), the evidence for use of Swahili-style cooking lids may appear paltrier. However, the importance of the Swahili-style lid lies not in its relative abundance or scarcity compared to other vessel shapes at Koromio, but instead in its clear indication of the persistence of coastal culinary practices at the site.

At both Makoroboi and Koromio, more ephemeral and less material aspects of coastal culture are also apparent. For example, local elder Jonathan Dunde reported that residents of Makoroboi spoke an understandable if imperfect Swahili amongst themselves (interviewed 24 October 2007); Swahili is the language of the coast. At Koromio, traveler and missionary Johann Ludwig Krapf (1845) mentioned that Koromio had "their own sheiks." A sheik is, of course, a Muslim elder or leader. The reported presence of sheiks hints at the potential for shared Muslim practice at the settlement. Few inland or hinterland groups had accepted either Christianity or Islam until much closer to the turn of the 20th century. Muslim practice, like Swahili language, would again point to coastal cultural influence. 
These material and non-material cultural patterns serve as a reminder to consider the full range of runaways' previous experiences. Maroons' entire life histories—including often substantial time in enslavement - contributed to their later acts of cultural creation in freedom. For example, in Suriname, runaways from the La Paix plantation joined together to create a community in exile; their descendants are today known as known as Lape lo, where 'lo' means matriclan. Similarly, runaways from the Du Perou plantation formed the group eventually known as Dipelu lo (Hoogbergen 1990:207). In the Americas, while newly enslaved people frequently attempted to run away, those who had been enslaved longer before absconding tended to be more successful in their attempts (Franklin and Schweninger 1999:209-233). How such refugees carried those experiences of enslavement forward into freedom is a process that archaeologists are well-situated to investigate and analyze.

\section{Indigenous Connections}

A more global approach to Maroon studies can also enrich our understanding of the connections that runaway slaves forged with free indigenes. Nearly one hundred years ago, Black studies pioneer Carter G. Woodson characterized the relationship between Africans and Native Americans as the "longest unwritten chapter" of African Diaspora history (Woodson 1920:45, quoted in Weik 2007:311). Maroon studies have helped to address this interpretive gap and to challenge the projection of modern racial categories into the past. Though marronage is often cast as a specifically African American experience in popular memory, archaeological data point to a Native American presence on nearly all excavated Maroon sites in the New World (Weik 2004:38). 
In Jamaica, Native American ceramics recovered at Nanny Town suggest that at least some "Arawak" people integrated with Maroons at the settlement rather than being wholly "exterminated" by the Spanish as had been previously intimated by some historians (Agorsah 1994:180-182, 2001:3; Fellows and Delle 2015:121). In Suriname, the Maroon village Kumako very likely included indigenous members as is shown by the integration of several local ritual elements including ahgbang, distinctively shaped pots used to mix ritually powerful substances (White 2009:78). In Suriname as a whole, archaeologists have characterized the relationship between Maroons and indigenes as symbiotic (Agorsah 2006b:200-201). In Florida, evidence for symbiosis is even clearer. The Maroons who were eventually called "Black Seminoles" not only maintained close military alliances with native Seminole groups but also drew much of their identity and cultural repertoire from Seminole norms and practices. At the Black Seminole Maroon sites Pilaklikaha, native pottery dominates the assemblage (Weik 2007:328); Pilaklikaha's imported artifacts also closely resemble those found on contemporary indigenous Seminole sites (Weik 2012:126-127)

In Brazil, at the large and socially complex Maroon polity Palmares, archaeological and documentary data suggest indigenous co-residence. An abundance of indigenous ceramics has been recovered from the site. While this material evidence is substantial, the documentary data are even more so. When Palmares was founded in the early 1600s, both Native Brazilians and Africans were routinely enslaved in Brazil; thus the earliest refugees from slavery who arrived at Palmares were not necessarily exclusively of African origin (Funari 2003:85; White 2010:477). Indeed, a written account of a 1644 raid on one Palmares village lists 35 inhabitants, seven of whom were Native Brazilian in addition to a few children of mixed ancestry (Rowlands 1999:333). Historical estimates of Palmares's population from the Portuguese and the Dutch 
further strengthen the case for indigenous residents. Many historians have been skeptical of contemporary estimates of Palmares's peak population at 20,000. However, when we consider the possibility of indigenous co-residence, such a high estimate becomes much more plausible (Orser 1992:7; Allen 2000). In addition, given Palmares's location some 80 kilometers from the coast, the first Maroons, whether African or Native Brazilian, would have required the cooperation of local indigenous groups in order to settle in the area (Rowlands 1999:339). Maroons' relationships with Native Americans were likely similarly crucial in the success or failure of all Maroon communities in the New World.

Like their counterparts in the Americas, refugees from slavery at Koromio and Makoroboi fostered close relationships with neighboring indigenous groups (Marshall 2015a). According to Johann Ludwig Krapf, a German missionary and explorer, Koromio residents maintained an ivory and cattle market at their settlement (Krapf 1846a). This market was run in cooperation with more mobile Waata hunters and Oromo herders, who likely also resided at Koromio at least during certain seasonal periods. The name of the settlement derives from its role in the cattle trade: Koromii means "bulls" in both Oromo and Waata (Stroomer 1987:347). This market is also reflected through archaeological remains at the site, including cattle bones and imported rice, ceramics, and beads. Though it displeased slave owners in nearby coastal towns like Takaungu (Figure 2), Omani colonial authorities in the major costal port Mombasa apparently condoned the market at Koromio (Krapf 1846a); this market allowed Mombasan merchants to sidestep indirect trading networks in which hinterland agriculturalist groups, such as the Giriama, acted as middlemen. Giriama traders typically brought ivory from Waata hunters and cattle from Oromo herders to coastal markets (Herlehy 1984:292-293, 296-297, 303). At Koromio, Mombasan merchants could access such goods directly from their producers (Krapf 
1846a; Morton 1978). The close relationship of watoro and, in particular, Waata people at Koromio is clear in Krapf's writings. While Krapf repeatedly describes Koromio as “inhabited by slaves who ran away from Suahili [sic] masters" (e.g., Krapf 1848a), he also once characterized the settlement as a "Dahalo [Waata] place" (Krapf 1846b).

The close ties forged between indigenes and runaway slaves at Makoroboi are even clearer. Nineteenth-century British missionaries called this village "Fuladoyo" in their correspondence; local Giriama elders today remember it as "Makoroboi;" "Fuladoyo" is now used by Giriama groups to reference a larger regional area. The place name "Makoroboi" derives from the English term "crew-boy," meaning someone in the service of Europeans (Sacleux 1939:440). Its use here stems from the village's Christian orientation and relationship with the Anglican Church Missionary Society. Makoroboi was founded in late 1879 by Abe Sidi, a Giriama convert who was also later known by his baptismal name David Koi. In November 1879, 14 runaway slaves came to Makoroboi seeking refuge and Koi permitted them to stay (Handford 1879). By March of the following year, the number of watoro at Makoroboi had risen to 44 (Menzies 1880); refugees from slavery would dominate the settlement's population until its demise in 1883 . Yet, even in the months before its destruction by slave owners, when Makoroboi had swelled to between 600 and 700 inhabitants (Handford 1885:167), the settlement was more defined by its Christian practice than its watoro majority. Makoroboi residents also included Giriama and Oromo converts, and the settlement's leadership remained with Koi until his murder during the 1883 attack (Hanford 1885:167; Stock 1899:92). Koi’s piety was also shared by many of his followers. In a first-hand account of a visit to the settlement, British missionary Anna Binns (1882) remarked, "we found with joy that some of them were true Christians." 
The presence of Giriama people at Makoroboi is most clear when comparing archaeological and historical data. All 144 house remains identified through surface survey at Makoroboi were burned wattle-and-daub. Of the two structures excavated, house shape could be determined at only one; there, post and wall remains indicated rectilinear orientation. These structures align with coastal house style in both their shape and earthen construction; they thus reflect architectural models adopted by watoro during enslavement. However, an 1882 sketch of three Makoroboi leaders, including David Koi, included a large round, grass-thatched house in the background (Price 1882:91); this structure closely aligns with Giriama architectural norms of the time. Thus, while grass-thatched round houses were not archaeologically identified at the site, their past presence at Makoroboi is likely, particularly given their more ephemeral material signature. The existence of grass-thatched round structures at Makoroboi points not just to the presence of Giriama inhabitants but also to the continued relevance of indigenous material cultural norms in the community.

So, we may reasonably ask: Was Makoroboi a Giriama village? Was Koromio a Waata place? Given their composite populations, there is a false tidiness to categorizing Makoroboi and Koromio as simply Maroon communities. These complications of site identification extend to the study of Maroons in the Americas. Sometimes, such issues have been couched as methodological in nature. Materially distinguishing runaway slaves from other groups wanting to disengage from colonial society has been a persistent challenge for archaeologists (e.g., Orser 1998:71; Weik 2012:61). Though some Maroon settlements, like Suriname’s Kumako (Agorsah 2007b:558), starkly contrast neighboring indigenous villages in either material culture or spatial organization, Native American and Maroon sites are most often materially similar. Archaeologists thus must frequently rely on oral and written histories for assistance in Maroon site identification. Where 
these histories are absent, assigning a definitive Maroon affiliation to an excavated site may not be possible (cf. Norton and Epenshade 2007, Chowdury 2015).

Recognizing these difficulties, Daniel Sayers declined to label the sites he surveyed in the Great Dismal Swamp as purely Maroon or indigenous settlements. Instead, he classified them according to what he called "modes of communitization," which he defined by distance from the swamp's edge and the concomitant degree of isolation from colonial society (Sayers et al. 2007:77-78, 81; Sayers 2014:109). Sayers importantly pointed out that the idea of a "pure" Maroon community is itself flawed as African runaways and Native Americans maintained a long history of living and working together throughout the Americas. Sayers (2008:275) noted, "We can be reasonably certain that communities [in the Great Dismal Swamp] did not form that were comprised only of Maroons, or [only of] Native Americans.” Terrance Weik (2012:135) likewise argued that Black Seminole settlements were "heterogeneous places, inhabited by different groups of Africans, African Americans, and Native Americans, all co-influencing each other."

Distinguishing Maroon and indigenous sites is not just a methodological challenge; rather, it is difficult because these "pure" categories depart from the instability and messiness of past realities. In The Art of Not Being Governed (2009) Anthropologist James C. Scott (2009:ix) argued that the Zomia hill communities of Southeast Asia, who have sometimes been cast as "primitive" holdouts, "are best understood as runaway, fugitive, maroon communities who have, over the course of two millennia, been feeling the oppressions of state-making projects in the valleys — slavery, conscription, taxes, corvée labor, epidemics, and warfare.” Scott (2009:190) explicitly linked hill peoples' strategies of state avoidance with those historically associated with runaway slaves - for example, living in ecologically marginal locales, staying mobile, practicing 
shifting cultivation, and engaging in raiding and clandestine trade. Many of these strategies were likewise adopted by oppressed indigenous communities in the Americas (White 2010:477; Baram 2012:110). Scott's broader argument is that marronage is a strategy that has been practiced by oppressed communities of many stripes - including groups never enslaved (see also Sayers 2015:183). His analysis underlines the fact that it may be our categories, more than our methodologies, that are failing us when attempting to distinguish Maroon and indigenous sites.

\section{Identity Making and Group Cohesion}

While the close ties that Maroons maintained with New World indigenes are clear, archaeologists are still unpacking how these relationships factor into Maroon identity. As we have seen, the very earliest Maroons were likely Native American. Maroons of African origin, who later become numerically dominant, derived from many parts of the continent. Even taking into account regional preferences for captives of specific ethnic affiliations, Maroon communities were unlikely to have been ethnically segregated in the New World (Agorsah 2003:736; cf. Orser 1998:71). In later periods of the slave trade, many refugees from slavery were African Americans, born on the continent of their captivity (Weik 2005:37). Some researchers have argued that, as Maroons were drawn from diverse cultural and social backgrounds, we should not expect their communities to be homogeneous in identity or culture. The heterogeneous origins of Maroons sometimes seem to be reflected in a parallel diversity in their material culture, such as the abundance of different rim forms found on Black Seminole pottery (Weik 2002:170, 2007:329). Yet, despite their demonstrated material and cultural diversity, Black Seminoles created a coherent and unified society that interwove African, European, and indigenous Seminole practices and beliefs (Weik 2002:167-168, 2007:330). 
Maroons banded together foremost for mutual protection and defense. Archaeologists have grown increasingly interested in the mechanisms by which such refugees created communities of broader cultural coherence with, in many cases, durable identities to pass down to their descendants (Agorsah 2001:1).

Archaeologists have explained Maroon identity and solidarity through three dominant models: (1) cultural mosaics, (2) creolization, and (3) ethnogenesis. Charles E. Orser, Jr. has been the most prominent champion of the cultural mosaic concept, which emphasizes the heterogeneity of Maroon groups. He observed that Palmares ceramics encompassed three distinct types: indigenous Brazilian wares, imported European wares, and a distinct, locally-made, wheel-turned ware (Allen 1998; Funari 2007:364). Orser (1994:13) argued that this "variation in the ceramic collection may reflect cultural differences present within Palmares." Documentary evidence suggests Palmares's population may have included some lower-class Portuguese and Dutch colonists in addition to Africans, African Brazilians, and Native Brazilians. The settlement's ceramic heterogeneity, Orser maintained, should be read as evidence of its diverse populace — best modeled as a cultural mosaic (Orser 1994, 1996; Funari 1999:320-321; Funari and de Carvalho 2012:260). Critiquing Orser's interpretive approach, Scott Joseph Allen argued that the cultural mosaic model propagates a static view of culture and a misplaced emphasis on ceramics as bearers of culture. Allen (1998:143) also pointed out that the mosaic's ethnic and cultural groups are modeled as discrete entities unto themselves. Beyond its inability to represent cultural identities and boundaries as dynamic, the cultural mosaic model's primary limitation is its inattention to the possible formation or maintenance of broader, shared Maroon identities. Archaeological models of creolization rely on a linguistic metaphor in which European lexicon (that is, material culture) is employed in African-derived or newly created African 
American syntax (that is, sociocultural structure) (Weik 2004:36). Creolization interpretations are most appropriate for those Maroon groups who maintained especially strong cultural ties with European colonialists. In Spanish Florida, enslaved people in nearby English colonies were offered sanctuary in return for conversion to Catholicism and support of the Spanish crown. Residents of the Floridian Maroon settlement Fort Mose appear to have been devoted Catholic converts; they also received considerable support from the Spanish government for protecting the nearby colonial town St. Augustine (Deagan and MacMahon 1995). However, even at Fort Mose, the weaknesses of a creolization interpretative approach are apparent; the model does not adequately represent fort residents' interactions with indigenous peoples or with other European groups. Archaeological evidence at the site includes items from ports antagonistic to Spanish rule (Reitz 1994; Weik 2004:40). While these imported objects do not necessarily indicate direct trade, they do reveal participation in economic networks beyond Spanish control. The creolization model's dualistic interpretation of Maroon identity formation is clearly overly simplistic.

Ethnogenesis is now perhaps the most popular interpretive model in Maroon studies. In his interpretation of identity at Palmares, Scott Joseph Allen (1998) championed an approach he termed reinterpretive syncretism, but which has been recognized by others as an essentially ethnogenic model (e.g., de Carvalho 2007:10). To form an ethnic identity and become "Palmarinos," Allen argued that Palmares residents adopted cultural elements from diverse origins but then renegotiated and reinterpreted them in a newly formed cultural system (Allen 1998:162; see also Fennell's [2007] concept of ethnogenic bricolage). Allen's model maintains some superficial similarities with creolization; it significantly differs, however, in both its recognition of the diverse cultural influences on Maroon groups and its greater attention to how 
these influences could be transformed through Maroons' reinterpretation of them. While Terrance Weik's (2002) ethnogenic interpretation of the Black Seminole village Pilaklikaha is similarly nuanced, Weik has more strongly emphasized the limitations of ethnogenic approaches. Weik (2012:49) notes, for example, ethnogenic interpretations tend to neglect how self-liberated communities built coalitions across lines of cultural difference and how newcomers were socialized into nascent shared norms. He also cautions archaeologists to pay close attention to specific, individual Maroon settlements' histories and organization, even where they may depart from the ethnogenic model's expectations (Weik 2012:48).

If we take up Weik's challenge, to pursue an understanding of each individual Maroon settlement on its own terms, where do Koromio and Makoroboi lead us? Like Maroon settlements in the Americas, Koromio and Makoroboi were clearly influenced by a wide variety of cultural currents - adornment practices that formerly enslaved people brought from their natal homelands, house style and foodways that residents adopted in enslavement, and trade activities and religious practices facilitated by hinterland indigenes and Europeans (Marshall 2012b). Yet each settlement's tenure ended after less than a decade, likely too brief for ethnogenesis to truly take hold. What is more telling in these cases is what happened in the wake of each settlement's destruction - an eventual near-total and reasonably seamless integration of former residents into neighboring hinterland groups. Unlike Maroon descendants in some parts of the New World, who have preserved a durable and ethnicized Maroon identity passed from their forbearers, the watoro descendants of Koromio and Makoroboi have become Waata, Giriama, and Oromo. They have become indigenous (Marshall 2015a).

In Eastern Africa, slave ancestry is still typically considered shameful. As I have noted elsewhere, "[s]ince allegations of slave ancestry imply both low social standing and outsider 
status, they may be used to undercut an individual's or a family's authority" (Marshall 2015a: 279). Despite these lasting negative associations, the historical integration of formerly enslaved people into indigene hinterland groups is widely recognized in such communities (e.g., Kingi Barisa, interviewed 15 October 2007; Mudhengi wa Chanze, interviewed 31 October 2007; Jonathan Dunde, interviewed 24 October 2007; Mkutano wa Fondo, interviewed 2 November 2007; Kenga wa Gona, interviewed 31 October 2007; Faini Hanga, interviewed 8 October 2007; Ngumbao Iha, interviewed 25 October 2007; Johana Karisa Katenge, interviewed 26 October 2007; Thuva Konde, interviewed 26 May 2008; Kalume wa Mwambire, interviewed 24 October 2007; Karisa Mweri, interviewed 31 October 2007).

In recounting Koromio’s destruction, missionary Johann Ludwig Krapf (1848b) noted that many residents escaped death or capture and that a significant number of displaced watoro residents integrated into allied Waata hunter-gatherer communities. Koromio's comparatively early inhabitation dates limit the utility of local oral history in unpacking this integrative process, and the settlement's sketchy historical imprint does not help matters. Yet, while the specific mechanisms by which integration occurred are not clear, the success of the integrative process is nonetheless apparent by the lack of self-identifying watoro descendants at Koromio or elsewhere in the coastal hinterland today.

At Makoroboi, our understanding of the integrative process is more robust, underpinned by strong local historical memory of the settlement and a substantial documentary account from British missionaries (Marshall 2015a). Giriama people elsewhere in the hinterland tended to use blood-brotherhood rituals to cement inter-ethnic bonds (Herlehy 1984). However, oral historians at Makoroboi report that the major integrative mechanism there was instead intermarriage between watoro men and local Giriama women. The numerical dominance of men at Makoroboi, 
as reported by oral historians, matches patterns of runaway slave demographics elsewhere in the world; young men were often the most likely to run away from enslavement (e.g., Franklin and Schweninger 1999:210-213). Watoro men's marriages with Giriama women differed in important ways from marriages with a Giriama groom — so much so that some elders even today dismiss these unions not as marriages at all but as a kind of co-habitation (Ngumbao Iha, interviewed 25 October 2007; Johana Karisa Katenge, interviewed 26 October 2007). A watoro groom, unlike his Giriama counterpart, paid no dowry to his new bride's family. He also moved to his new wife's familial homestead and adopted his wife's clan affiliation, reversing the gendered expectation of typical patrilocal and clan exogamous Giriama marriages (Champion 1967:12-14). Most seriously, a watoro husband retained limited rights over his own children; these children instead "belonged" to the head of the Giriama homestead in which his family resided (Johana Karisa Katenge, interviewed 26 October 2007). Some watoro men were also given new Giriama names upon marriage to cement their new ethnic and clan affiliations (Kalume wa Mwambire, interviewed 24 October 2007).

What is important and distinctive in the histories of both Koromio and Makoroboi is that Maroon heritage did not provide a foundation for a durable ethnicized identity. Rather, watoro are today remembered as a generation that died and disappeared (Jonathan Dunde, interviewed 24 October 2007). While we should not idealize this integrative process, given the clearly reduced social position of Makoroboi watoro men in their new Giriama families, it is nonetheless a striking contrast to many New World groups. Slave heritage, much less watoro heritage, is rarely acknowledged at all in Eastern Africa today. While gossip about slave ancestry may still occasionally surface, watoro descendants are now firmly established as hinterland indigenes. The integration of slave descendants elsewhere in Eastern Africa has been more fractured at times. 
For example, on the Swahili Coast itself, descendants of formerly enslaved people often claimed Swahili or other coastal indigene identities following emancipation. Yet, despite adopting these new ethnonyms, slave descendants disproportionally suffered land dispossession on the coast as "squatters" during both the colonial and independence eras (Cooper 1981; Benjamin 2006; Marshall and Kiriama in press).

To understand the broader significance of the indigenization of watoro in Kenya, we may look north, to runaway slave communities in the Jubba River Valley of southern Somalia. There, thousands of refugees from slavery established independent agriculturalist settlements; Somali pastoralists, both slaveholders and non-slaveholders, historically avoided the valley because of the prevalence of tsetse flies, which posed significant risks to the health of livestock. Descendants of refugees from slavery who settled in the Jubba River Valley have long suffered lesser social status in Somali society. Gosha, translating as "sickly forest," refers in Somali both to the valley territory as well as to the communities who have historically resided there. A more common and derogatory designation is Jareer, from tiin jareer which translates literally as "hard hair." Gosha communities are recognized as a physically distinctive population in Somalia; they are widely believed to have darker skin, curlier hair, broader noses, and stockier frames than ethnically Somali people (Besteman 1999:116; Declich 2000:34). In recent decades, Jareer has been broadly glossed as "Somali Bantu" by English-speaking aid workers and journalists reporting on Somalia's civil war and subsequent refugee crisis (Besteman 1999:115). This designation, however, is not in common local use even now.

Many people enslaved by Somalis originated in southeastern Africa, along some of the same well-worn trade routes that brought captives to the Swahili Coast. Compared to ethnically Somali people, slave descendants in the Jubba River Valley have suffered a heightened and long- 
standing vulnerability to outside exploitation. In the 1930s, Italian colonialists confiscated Gosha land and forced the farmers they displaced into compulsory labor programs (Menkhaus 1996:142-143; Declich 2000:34). In 1975, an independent Somalia enacted land registration legislation, which allowed politically well-connected outsiders to continue to usurp the land of Gosha agriculturalists, including plots that had been farmed for several generations (Menkhaus 1996:147). In the state's failed 1977 war against Ethiopia, southern Gosha agriculturalists bore the brunt of the conflict, including confiscation of crop surpluses for the war effort (Cassanelli 1996:18); Gosha men were also frequently kidnapped by the state military and sent north to serve on the Ethiopian front (Besteman 1999:128-129). In the violence that followed the 1991 overthrow of long-standing dictator Mohamed Siad Barre, inhabitants of Somalia's Jubba River Valley suffered extensive looting, widespread rape, and frequent assault. Tellingly, both the state-backed Somali Patriotic Movement and oppositional militias, such as the United Somali Congress, posed serious threats to the safety of Gosha communities following the state's collapse (Menkhaus 1996:150-151).

The continued public recognition of Gosha people's slave heritage and their resulting racialization have, without question, done them material harm. Yet, Gosha people's lack of integration into broader Somali society has not been for lack of trying. Gosha communities have long participated in the Somali clan system. Their chosen clan affiliations, however, have often been delegitimized by outsiders and Somalis alike. One Gosha interviewee mimicked Italian colonists scolding Gosha farmers: 'I don’t accept you saying 'I am Mushunguli,' 'I am Bartire,' 'I am Shabeelle,' 'I am Cawlyahan,' 'I am Marexan.' These don't exist for you. You are all lying ... You have to participate [in the forced labor program]" (Besteman 1995:52). Like Italian colonists, Somalis viewed Gosha claims to clan affiliation as somewhat less than authentic. 
Beyond their distinctive economic strategies as farmers (rather than herders), Gosha people's lack of success integrating into Somali society is rooted in the ease with which they could be physically distinguished from ethnically Somali people (Declich 2010:170). Unlike watoro in Kenya, Gosha runaways and their descendants looked different from local indigenes in Somalia; they often could be picked out at a glance (Cassanelli 1987:218).

Turning our attention back to Maroon communities in the Americas, we may note that, like Gosha people in Somalia, African-descendant Maroons in the New World were typically physically distinctive from neighboring Native American groups. Given watoro's fairly seamless integration into neighboring free communities in Kenya, we need to more carefully consider the constraints under which Maroon ethnogenesis operated in the New World. A widened geographic frame helps us more clearly identify the role of racialization in promoting ethnogenesis in the Americas. Even generations after emancipation, the non-indigenous heritage of Maroon descendants in the New World was visually marked; a lack of physical similitude may have made integration with Native Americans more difficult.

\section{Conclusion}

While this essay has presented three prominent interpretive themes in Maroon archaeology as discrete entities, they are of course tightly interwoven and interdependent. For example, the cultural strands that refugees from slavery carried into freedom provided much of the foundation upon which they created a sense of group cohesion. Similarly, the strength and character of the relationships that runaway slaves forged with indigenes affected Maroon community formation - specifically whether their descendants forged a durable ethnicized identity or instead melded into indigenous groups, identities, and lifeways. 
This article's analysis of “Africanisms," connections to indigenes, group cohesion, and identity creation has highlighted sometimes stark distinctions between marronage in Eastern Africa and marronage in the Americas. Watoro in Kenya and Maroons in the New World varied in substantive and significant ways. Yet, what end or purpose might these comparisons serve? That is, if marronage was different in Eastern Africa, so what? Do the case studies presented here merely constitute a historical curiosity? Is the Kenyan coastal hinterland so far culturally and geographically removed as to be irrelevant to the escape of African captives in the New World? How is the view from Kenya presented in this article useful to Americanists? In her recent excellent Capitalism and Cloves, Sarah Croucher (2015) used her research on plantations in 19th-century Zanzibar to upend the entrenched definitions of "plantation," "slavery," and "resistance" often adopted by historical archaeologists in the New World. Croucher framed her work comparatively with plantation archaeology in North America and the Caribbean, and her analysis worked to decenter and provincialize plantation organization in these areas. That is, she helped to illustrate the specific historical and cultural conditions that shaped plantation regimes in both Zanzibari and American contexts. In the same way, studying marronage in Kenya may highlight, by contrast, the specific historical and cultural circumstances that conditioned marronage in various New World settings. For example, a globalized perspective may contrast the persistence of ethnicized Maroon identities in some New World areas with the typical Kenyan understanding of watoro as a generation that passed away. Thus, a comparative framework prompts greater analytical attention to the role of racialization in Maroon ethnogenesis in the New World as well as Maroons' concomitant difficulty integrating fully into Native American groups. Indeed, while some New World Maroon communities have persisted to the present, Koromio and Makoroboi were each occupied for less than a decade. 
Archaeologists, like anthropologists more broadly, confront a basic tension in their field between local and global perspectives - that is, between culturally and historically contextualized interpretations and more comparative, less particularistic analyses. Is the purpose of archaeology to present case studies with the richest level of cultural detail and specificity possible? Or should archaeologists use broader comparative frameworks to better understand the shared human condition? This article argues that these goals are not mutually exclusive (Marshall 2015b:16-17). Rather, a global and comparative perspective can underpin more thoroughly local and historically specific understandings of both watoro in Kenya and Maroons throughout the Americas.

Acknowledgments

I am grateful for the assistance and advice of current and past staff at the Coastal Archaeology Division of the National Museums of Kenya, including Jambo Haro, Dr. Herman Kiriama, Ibrahim Busolo, George Ghandi, Philip Wanyama, Mohamed Mchulla Mohamed, and the late Kaingu Kalume Tinga. Thanks also to landowners at Koromio and Makoroboi, including Kaingu Hanga, Nyevu Menza, Kang’ombe Nzaro Moka, and Karisa Iha Nyundo, for permitting excavation. I am grateful to Drs. Adria LaViolette, Jeffrey Hantman, Joseph Miller, and Patricia Wattenmaker for their guidance of the larger dissertation project from which this article originated. Appreciation is also due to Dr. Sarah Walshaw for archaeobotanical analysis and Ogeto Mwebi and his team (Osteology Department, National Museums of Kenya) for faunal analysis. The British Institute in Eastern Africa, particularly former directors Drs. Paul Lane and Justin Willis and former assistant director Dr. Stephanie Wynne-Jones, provided invaluable logistical advice and support. I am also very thankful for my colleagues in the Department of 
Sociology and Anthropology at DePauw University and their unfailing support and encouragement. Finally, I am indebted to Dr. Edward Alpers, two anonymous reviewers, and Historical Archaeology Journal Associate Editor Dr. Jonathan Walz for materially improving this article's clarity and argument. A preliminary season of fieldwork in summer 2006 was supported by the Explorers Club Washington Group and the University of Virginia Graduate School of Arts and Sciences. Fieldwork in 2007-2008 was funded by a Fulbright-Hays Dissertation Research Abroad Fellowship (\#P022A070037), a National Science Foundation Doctoral Dissertation Research Improvement Grant (\#0733784), and an International Dissertation Research Fellowship from the Social Science Research Council. Additional financial support for this project was provided by a National Science Foundation Graduate Research Fellowship and a Dissertation Completion Fellowship from the Andrew W. Mellon Foundation/American Council of Learned Societies Early Career Fellowship Program.

Conflict of Interest Statement There is no conflict of interest.

References

Agorsah, E. Kofi

1993 Archaeology and Resistance History in the Caribbean. The African Archaeological Review 11(1):175-196.

1994 Archaeology of Maroon Settlements in Jamaica. In Maroon Heritage: Archaeological Ethnographic and Historical Perspectives, E. Kofi Agorsah, editor, pp. 163-187. Canoe Press, Kingston, Jamaica. 
1995 Redefining Maroon Heritage in the New World Studies. In Proceedings of the 16th International Congress for Caribbean Archaeology, Richard Gerard, editor, pp. 224-234.

Conseil Régional de la Guadeloupe and Auditorium de la Ville de Basse Terre, Basse Terre, Guadeloupe.

1999 Ethnoarchaeological Consideration of Social Relationship and Settlement Patterning among Africans in the Caribbean Diaspora. In African Sites Archaeology in the Caribbean, Jay B. Haviser, editor, pp. 38-64. M. Weiner Publishers, Princeton, NJ.

2001 The Secrets of Maroon Heroism as Pioneer Freedom Fighters of the African Diaspora. In Freedom in Black History and Culture, E. Kofi Agorsah, editor, pp.1-17. Arrow Point Press, Middletown, CA.

2003 Tracking Down the Maroons: Archaeo-Geography of Marronage in the Caribbean. In Proceedings of the 20th International Congress for Caribbean Archaeology, Vol. 2, Clenis Tavárez María and Manuel A. García Arévalo, editors, pp.732-742. Museo del Hombre Dominicano and Fundación Garía Arévalo, Santo Domingo, Dominican Republic. 2006a Freedom, Geography, and Maroon Military Strategies. In Africa and the African Diaspora: Cultural Adaptation and Resistance, E. Kofi Agorsah and G. Tucker Childs, editors, pp. 175-203. Authorhouse, Bloomington, IN.

2006b The Other Side of Freedom: The Maroon Trail in Suriname. In African Re-Genesis:

Confronting Social Issues in the Diaspora, Jay B. Haviser and Kevin C. MacDonald, editors, pp. 191-203. UCL Press, London, UK.

2007a Scars of Brutality: Archaeology of the Maroons in the Caribbean. In Archaeology of Atlantic Africa and the African Diaspora, Akinwumi Ogundiran and Toyin Falola, editors, pp. 332-354. Indiana University Press, Bloomington. 
2007b New Trends in Maroon Archaeology in Suriname - Transformation Processes. In Proceedings of the 21st Congress of the International Association for Caribbean Archaeology, Vol. 2, Basil Reid, Henri Petitjean Roget, and Antonio Curet, editors, pp. 555-563. School of Continuing Studies, University of the West Indies, St. Augustine, Trinidad.

Allen, Scott Joseph

1998 A 'Cultural Mosaic' at Palmares?: Grappling with the Historical Archaeology of a Seventeeth-Century Brazilian Quilombo. In Cultura Material e Arqueologia Histórica, Pedro P.A. Funari, editor, pp. 141-78. Instituto de Filosofia e Ciêcias Humanas de UNICAMP, Campinas, Brazil.

2000 Identidades em Jogo: Negros, Índios e a Arqueologia da Serra da Barriga. In Índios do Nordeste: Temas e Problemas, Vol. 2, L. de Almeida, M. Galindo and J. Elias, editors, pp. 245275. Editora da Universidade Federal de Alagoas, Maceió, Brazil.

2001 “Zumbi Nunca Vai Morrer”: History, the Practice of Archaeology, and Race Politics in Brazil. Doctoral dissertation, Department of Anthropology, Brown University. University Microfilms International, Ann Arbor, MI.

Alpers, Edward A

1967 The East African Slave Trade. East African Publishing House, Nairobi, Kenya. 1997 The Story of Swema: Female Vulnerability in Nineteenth-Century East Africa. In Women and Slavery in Africa, Claire C. Robertson and Martin A. Klein, editors, pp. 185-199. Heinemann, Portsmouth, NH. 
2003 Flight to Freedom: Escape from Slavery among Bonded Africans in the Indian Ocean World, c.1750-1962. Slavery \& Abolition 24(2):51-68.

Anderson, Kaj Blegvad

1977 African Traditional Architecture: A Study of the Housing and Settlement Patterns of Rural Kenya. Oxford University Press, Oxford, UK.

Armstrong, Douglas V.

2011 Reflections on Seville: Rediscovering the African Jamaican Settlements at Seville Plantation, St. Ann's Bay. In Out of Many, One People: The Historical Archaeology of Colonial Jamaica, J.A. Delle, M.W. Hauser, and D.V. Armstrong, editors, pp. 77-101. The University of Alabama Press, Tuscaloosa.

Baram, Uzi

2012. Cosmopolitan Meanings of Old Spanish Fields: Historical Archaeology of a Maroon Community in Southwest Florida. Historical Archaeology 46(1):108-122.

Barrett, W.E.H.

1911 Notes on the Customs and Beliefs of the Wa-Giriama, Etc., British East Africa. Journal of the Royal Anthropological Institute of Great Britain and Ireland 41(1):20-39.

Beachey, R.W. 
1976a The Slave Trade of Eastern Africa: A Collection of Documents. Barnes and Noble, New York, NY.

1976b The Slave Trade of Eastern Africa. Barnes and Noble, New York, NY.

Beech, Mervyn W.H.

1916 Slavery on the East Coast of Africa. Journal of the Royal African Society 15(58):145-149.

Benjamin, Jesse

2006 Squatters, Resistance to "Development”, and Magic as a Tool of Subaltern Power: A Case from Coastal Kenya." In Studies in Witchcraft, Magic, War and Peace in Africa: Nineteenth and Twentieth Centuries, Beatrice Nicolini, editor, pp. 239-262. The Edwin Mellen Press, Lewiston, ME.

Besteman, Catherine

1995 The Invention of Gosha: Slavery, Colonialism, and Stigma in Somali History. In The Invention of Somalia, Ali Jimale Ahmed, editor, pp. 43-62, Red Sea Press, Lawrenceville, NJ. 1999 Unraveling Somalia: Race, Violence, and the Legacy of Slavery. University of Pennsylvania Press, Philadelphia.

Bilby, Kenneth

2005 True-Born Maroons. University Press of Florida, Gainesville.

Binns, Anna 
1882 Journal Entry, 4 October. Manuscript, H.K. Binns Journals \& Photo Albums, Kenya National Archives, Microfilm 2234, Reel 001-002, Syracuse University.

Brooks, Alasdair and Ruth Young

2016 Historical Archaeology and Heritage in the Middle East: A Preliminary Overview. Historical Archaeology 50(4):22-35.

Brown, Kenneth L.

2015 Retentions, Adaptations, and the Need for Social Control within Africa and African American Communities across the Southern United States from 1770 to 1930. In The Archaeology of Slavery: A Comparative Approach to Captivity and Coercion, Lydia Wilson Marshall, editor, pp. 166-191, Center for Archaeological Investigations, Southern Illinois University Carbondale, Occasional Paper No. 41, Southern Illinois University Press, Carbondale.

Burton, Richard F.

1860 The Lake Regions of Central Africa: A Picture of Exploration, Vol. 1. Harper and Brothers, New York.

Cassanelli, Lee V.

1987 Social Construction on the Somali Frontier: Bantu Former Slave Communities in the Nineteenth Century. In The African Frontier: The Reproduction of Traditional African Societies, Igor Kopytoff, editor, pp. 216-238. University of Indiana Press, Bloomington.

1996 Explaining the Somali Crisis. In The Struggle for Land in Southern Somalia: The 
War behind the War, Catherine Besteman and Lee V. Cassanelli, editors, pp. 13-26, Westview Press, Boulder, CO.

Champion, Arthur M.

1967 The Agiryama of Kenya. Royal Anthropological Institute of Great Britain and Ireland, Occasional Paper No. 25, London, UK.

Chowdury, Amitava

2015 Maroon Archaeological Research in Mauritius and Its Possible Implications in a Global Context. In The Archaeology of Slavery: A Comparative Approach to Captivity and Coercion, Lydia Wilson Marshall, editor, pp. 255-275, Center for Archaeological Investigations, Southern Illinois University Carbondale, Occasional Paper No. 41, Southern Illinois University Press, Carbondale.

Cooper, Frederick

1977 Plantation Slavery on the East Coast of Africa, Yale University Press, New Haven, CT. Reprinted 1997 by Heinemann, Portsmouth, NH.

1980 From Slaves to Squatters: Plantation Labor and Agriculture in Zanzibar and Coastal Kenya, 1890-1925. Yale University Press, New Haven, CT. Reprinted 1997 by Heinemann, Portsmouth, NH.

1981 Islam and Cultural Hegemony: The Ideology of Slaveowners on the East African Coast. In The Ideology of Slavery in Africa, Paul E. Lovejoy, editor, pp. 271-307, Sage Publications, Beverly Hills, CA. 
Croucher, Sarah

2006 Plantations on Zanzibar: An Archaeological Approach to Complex Identities. Doctoral dissertation, Department of Archaeology, University of Manchester, University Microfilms International, Ann Arbor, MI.

2015 Capitalism and Cloves: An Archaeology of Plantation Live on Nineteenth-Century

Zanzibar. Springer, New York, NY.

Davies, Peter

2013 Archaeology and Religion at the Hyde Park Barracks Destitute Asylum, Sydney. Historical Archaeology 47(4):86-102.

Deagan, Kathleen and Darcie MacMahon 1995 Fort Mose: Colonial America's Black Fortress of Freedom. Florida Museum of Natural History, University Press of Florida, Gainesville.

de Carvalho, Aline Vieira

2007 Archeological Perspectives of Palmares: A Maroon Settlement in $17^{\text {th }}$ century Brazil. African Diaspora Archaeology Newsletter (March 2007).

<http://www.diaspora.uiuc.edu/news0307/news0307-5.pdf>. Accessed April 7, 2017.

Declich, Francesa 
2000 Fostering Ethnic Reinvention: Gender Impact of Forced Migration on Bantu Somali Refugees in Kenya. Cahiers d'Études Africaines 40(157): 25-53.

2010 Can Boundaries not Border on One Another?: The Zigula (Somali Bantu) between Somalia and Tanzania. In Borders \& Borderlands as Resources in the Horn of Africa, Dereje Feyissa and Markus Virgil Hoehne, editors, pp. 169-186. James Currey, Woodbridge, Suffolk, UK.

Diouf, Sylviane A.

2003 Fighting the Slave Trade: West African Strategies. Ohio University Press, Athens.

Fellows, Kristen R. and James A. Delle

2015 Marronage and the Dialectics of Spatial Sovereignty in Colonial Jamaica. In Current Perspectives on the Archaeology of African Slavery in Latin America, Pedro Paulo A. Funari and Charles E. Orser, Jr, editors, pp.117-132. Springer, New York, NY.

Fennell, Christopher C.

2007 Crossroads and Cosmologies: Diasporas and Ethnogenesis in the New World. University Press of Florida, Gainesville.

Ferguson, Leland

1992 Uncommon Ground: Archaeology and Early African America, 1650-1800. Smithsonian Institution Press, Washington, DC.

Franklin, John Hope and Loren Schweninger 
1999 Runaway Slaves: Rebels on the Plantation. Oxford University Press, Oxford, UK.

Frazier, E. Franklin

1949 The Negro in the United States. MacMillan, New York, NY.

Funari, Pedro Paulo A.

1995 The Archaeology of Palmares and Its Contribution to the Understanding of the History of African-American Culture. Historical Archaeology in Latin America 7:1-41.

1999 Maroon, Race, and Gender: Palmares Material Culture and Social Relations in a Runaway Settlement. In Historical Archaeology: Back from the Edge, Pedro

Paulo A. Funari, Martin Hall, and Siân Jones, editors, pp. 308-327. Routledge, New York, NY. 2003 Conflict and Interpretation of Palmares, a Brazilian Runaway Polity. Historical Archaeology 37(3):81-92.

2007 The Archaeological Study of the African Diaspora in Brazil. In Archaeology of Atlantic Africa and the African Diaspora, Akinwumi Ogundiran and Toyin Falola, editors. pp. 355-371. Indiana University Press, Bloomington.

Funari, Pedro Paulo A. and Aline Vieira de Carvalho 2012 Gender Relations in a Maroon Community, Palmares, Brazil. In The Archaeology of Colonialism: Intimate Encounters and Sexual Effects, Barbara L. Voss and Eleanor Conlin Casella, editors, pp. 252-270. Cambridge University Press, UK.

Funari, Pedro Paulo A. and Lúcio Menezes Ferreira 
2016 Historical Archaeology Outlook: A Latin American Perspective. Historical Archaeology 50(3):100-110.

Gissing, C.E.

1884 A Journey from Mombasa to Mounts Ndara and Kasigao. Proceedings of the Royal Geographical Society and Monthly Record of Geography, New Monthly Series, 6(10):551-566.

Glassman, Jonathon

1991 The Bondsman's New Clothes: The Contradictory Consciousness of Slave Resistance on the Swahili Coast. Journal of African History 32(2): 277-312.

1995 Feasts and Riot: Revelry, Rebellion, and Popular Consciousness on the Swahili Coast, 1856-1888. Heinemann, Portsmouth, NH.

Guha, Sumit

2006. Slavery, Society, and the State in Western India, 1700-1800. In Slavery and South Asian

History, Indrani Chatterjee and Richard M. Eaton, editors, pp. 162-186. Indiana University Press, Bloomington.

Handford, John W.

1879 Letter to H. Wright, 12 February. Manuscript, Section IV: Africa Missions, Part 16: South Africa, 1836-1843, Kenya, 1841-1888, and Nyanza, 1876-1882, Reel 321, CA5/O11: Original Papers. London: Church Missionary Society Archive. 
1885 The Freed Slaves at Frere Town. Church Missionary Intelligencer and Record, New Series 10(3):158-167.

Herlehy, Thomas J.

1984 Ties That Bind: Palm Wine and Blood-Brotherhood at the Kenya Coast during the 19th Century. International Journal of African Historical Studies 17(2):285-308

Herskovits, Melville J.

1941 The Myth of the Negro Past. Harper and Brothers, New York, NY.

Hoogbergen, Wim S.M.

1990 The Boni Maroon Wars in Suriname. E.J. Brill, Leiden, the Netherlands.

Kirkman, James

1974 Fort Jesus: A Portuguese Fortress on the East African Coast. Oxford University Press, Oxford, UK.

Handford, John W.

1879 Letter to H. Wright, 12 February. Manuscript, Section IV: Africa Missions, Part 16: South Africa, 1836-1843, Kenya, 1841-1888, and Nyanza, 1876-1882, Reel 321, CA5/O11: Original Papers. London: Church Missionary Society Archive.

Krapf, Johann Ludwig 
1845 Letter to Lay Secretary, June 7. Manuscript, Section IV: Africa Missions, Part 16: South Africa, 1836-1843, Kenya, 1841-1888, and Nyanza, 1876-1882, Reel 317, CA5/M1: Mission Book, 1842-1846. London: Church Missionary Society Archive.

1846a Journal Entry, 25 February. Manuscript, Section IV: Africa Missions, Part 16: South Africa, 1836-1843, Kenya, 1841-1888, and Nyanza, 1876-1882, Reel 317, CA5/M1: Mission Book, 1842-1846. London: Church Missionary Society Archive.

1846b Journal Entry, 13 March. Manuscript, Section IV: Africa Missions, Part 16: South Africa, 1836-1843, Kenya, 1841-1888, and Nyanza, 1876-1882, Reel 317, CA5/M1: Mission Book, 1842-1846. London: Church Missionary Society Archive.

1848a Letter to Henry Venn, 16 November. Manuscript, Section IV: Africa Missions, Part 16:

South Africa, 1836-1843, Kenya, 1841-1888, and Nyanza, 1876-1882, Reel 318, CA5/M2:

Mission Book, 1846-1856. London: Church Missionary Society Archive.

1848b Journal Entry, 29 December. Manuscript, Section IV: Africa Missions, Part 16: South Africa, 1836-1843, Kenya, 1841-1888, and Nyanza, 1876-1882, Reel 318, CA5/M2: Mission Book, 1846-1856. London: Church Missionary Society Archive.

2002 Memoir on the East African Slave Trade, ein unveröffentlichtes Dokument aus dem Jahr 1853. Afro-Pub, Wien, Germany.

Labelle, Marie-Louise 2005 Beads of Life: Eastern and Southern African Beadwork from Canadian Collections. Canadian Museum of Civilization, Mercury Series, Cultural Studies Paper 78. Gatineau, Quebec, Canada. 
La Rosa Corzo, Gabino

2005 Subsistence of Cimarrones: An Archaeological Study. In Dialogues in Cuban Archaeology,

L. Antonio Curet, Shannon Lee Dawdy, and Gabino La Rosa Corzo, editors, pp. 163-180.

University of Alabama Press, Tuscaloosa.

Livingstone, David and Charles Livingstone

1865 Narrative of an Expedition to the Zambesi and its Tributaries; and of the Discovery of the Lakes Shirwa and Nyasa, 1858-1864. John Murray, London.

Mapunda, Bertram B.B.

2017 Encounter with an "Injured Buffalo:” Slavery and Colonial Emancipation in Tanzania. Journal of African Diaspora Archaeology and Heritage 6(1):1-18.

Marshall, Lydia Wilson

2011 Fugitive Slaves and Community Creation in 19th-Century Kenya: An Archaeological and Historical Investigation of Watoro Villages. Doctoral dissertation, Department of Anthropology, University of Virginia. University Microfilms International, Ann Arbor, MI.

2012a Typological and Interpretive Analysis of a 19th-Century Bead Cache in Coastal Kenya. Journal of African Archaeology 10(2):189-205.

2012b Spatiality and the Interpretation of Identity Formation: Fugitive Slave Community Creation in 19th-Century Kenya. African Archaeological Review 29(4):355-381.

2015a Marronage and the Politics of Memory: Fugitive Slaves, Interaction, and Integration in 19th-Century Kenya. In The Archaeology of Slavery: A Comparative Approach to Captivity and 
Coercion, Lydia Wilson Marshall, editor, pp. 276-299, Center for Archaeological Investigations, Southern Illinois University Carbondale, Occasional Paper No. 41, Southern Illinois University Press, Carbondale.

2015b Introduction: The Comparative Archaeology of Slavery. In The Archaeology of Slavery: A Comparative Approach to Captivity and Coercion, Lydia Wilson Marshall, editor, pp. 1-23, Center for Archaeological Investigations, Southern Illinois University Carbondale, Occasional Paper No. 41, Southern Illinois University Press, Carbondale.

Marshall, Lydia Wilson and Herman Kiriama

In press The Legacy of Slavery on the Swahili Coast. In The Swahili World, Stephanie WynneJones and Adria LaViolette, editors, pp. 566-576. Routledge, New York.

McKim, Wayne

1985 House Types in Tanzania: A Century of Change. Journal of Cultural Geography 6(1):5177.

Menkhaus, Kenneth

1996 From Feast to Famine: Land and the State in Somalia's Lower Jubba Valley. In The Struggle for Land in Southern Somalia: The War behind the War, Catherine Besteman and Lee V. Cassanelli, editors, 133-153. Westview Press, Boulder, CO.

Menzies, Alfred 
1880 Letter to H. Wright, 15 July. Manuscript, Section IV: Africa Missions, Part 16: South Africa, 1836-1843, Kenya, 1841-1888, and Nyanza, 1876-1882, Reel 322, CA5/O18:

Original Papers, 1879-1880. London: Church Missionary Society Archive.

Morton, R. Frederick

1978 A Reappraisal of the History of Wata Hunters of the Kenya Coast in the Pre-Colonial Era. Kenya Historical Review 6:23-56.

1990 Children of Ham: Freed Slaves and Fugitive Slaves on the Kenya Coast, 1873 to 1907. Westview Press, Boulder, CO.

Nichols, Elaine

1988 No Easy Run to Freedom: Maroons in the Great Dismal Swamp of North Carolina and Virginia, 1677-1850. Master's thesis, Department of Anthropology, University of South Carolina, Columbia.

Norton, Holly K. and Christopher T. Epenshade 2007 The Challenge in Locating Maroon Refuge Sites at Maroon Ridge, St.Croix. Journal of Caribbean Archaeology 7.

<http://www.flmnh.ufl.edu/files/5313/9445/7987/nortonandespenshade.pdf>. Accessed April 7 2017.

Ogundiran, Akinwumi and Toyin Falola 
2007 Pathways in the Archaeology of Transatlantic Africa. In Archaeology of Atlantic Africa and the African Diaspora, Akinwumi Ogundiran and Toyin Falola, editors, pp. 3-48. Indiana University Press, Bloomington.

Orser, Charles E., Jr.

1992 In Search of Zumbi: Preliminary Archaeological Research at the Serra da Barriga, State of Alagoas, Brazil. Midwestern Archaeological Research Center, Illinois State University, Normal. 1994 Toward a Global Historical Archaeology: An Example from Brazil. Historical Archaeology 28(1):5-22.

1996 A Historical Archaeology of the Modern World. Plenum Press, New York, NY. 1998 Archaeology of the African Diaspora. Annual Review of Anthropology 27:63-82.

Orser, Charles E., Jr. and Pedro Paulo A. Funari

2001 Archaeology and Slave Resistance and Rebellion. World Archaeology 33(1):61-72.

Otto, John Solomon 1984 Canon's Point Plantation: 1794-1860: Living Conditions and Status Patterns in the Old South. Academic Press, Orlando, FL.

Posnansky, Merrick

2013. Digging through Twentieth-Century Rubbish at Hani, Ghana. Historical Archaeology 47(2):64-75. 
Prestholdt, Jeremy

2008 Domesticating the World: African Consumerism and Genealogies of Globalization.

University of California Press, Berkeley.

Price, Richard

1973 Maroon Societies: Rebel Slave Communities in the Americas. Anchor Press, New York.

1983 First-Time: The Historical Vision of an Afro-American People. Johns Hopkins University

Press, Baltimore, MD.

Price, William Salter

1882 Notes from East Africa. Church Missionary Gleaner 9(103):90-92.

Reitz, Elizabeth J.

1994 Zooarchaeological Analysis of a Free African Community: Gracia Real de Santa Teresa de Mose. Historical Archaeology 28(1):23-40.

Robertson, Claire C.

1997. Gender and Trade Relations in Central Kenya in the Late Nineteenth Century. International Journal of African Historical Studies 30(1):23-47.

Rowlands, Michael 
1999 Black Identity and Sense of Past in Brazilian National Culture. In Historical Archaeology:

Back from the Edge, Pedro Paulo A. Funari, Martin Hall, and Siân Jones, editors, pp. 328-344. Routledge, New York, NY.

Sacleux, Charles

1939 Dictionnarie Swahili-Français. Institut d'Ethnologie, Paris, France.

Samford, Patricia

1999 Strong is the Bond of Kinship: West African Ancestor Shrines and Subfloor Pits on African-American Quarters. In Historical Archaeology, Identity Formation, and the Interpretation of Ethnicity, Maria Franklin and Garrett Fesler, editors, pp. 71-92. Colonial Williamsburg Foundation, Dietz Press, Richmond, VA.

Sayers, Daniel O.

2008 The Diasporic World of the Great Dismal Swamp, 1630-1865. Doctoral dissertation, Department of Anthropology, College of William and Mary. University Microfilms International, Ann Arbor, MI.

2012 Marronage Perspective for Historical Archaeology in the United States. Historical Archaeology 46(4):135-161.

2014 A Desolate Place for a Defiant People: The Archaeology of Maroons, Indigenous Americans, and Enslaved Laborers in the Great Dismal Swamp. University Press of Florida, Gainesville. 
2015. Scission Communities and Social Defiance: Marronage in the Diasporic Great Dismal Swamp, 1660-1860. In The Limits of Tyranny: Archaeological Perspectives on the Struggle against New World Slavery, James A. Delle, editor, pp. 177-211. The University of Tennessee Press, Knoxville.

Sayers, Daniel O., P. Brendan Burke, and Aaron M. Henry 2007 The Political Economy of Exile in the Great Dismal Swamp. International Journal of Historical Archaeology 11(1):60-97.

Scott, James C.

2009 The Art of Not Being Governed: An Anarchist History of Upland Southeast Asia. Yale University Press, New Haven, CT

Sheriff, Abdul M.H.

1985 The Slave Mode of Production along the East African Coast, 1810-1873. In Slaves and Slavery in Muslim Africa, John Ralph Willis, editor, pp. 161-181. Cass, London, UK 1987 Slaves, Spices \& Ivory in Zanzibar: Integration of an East African Commercial Empire into the World Economy, 1770-1873. James Currey, London, UK.

Stanley, Henry Morton

1872 How I Found Livingstone: Travels, Adventures, and Discoveries in Central Africa. Scribner, Armstrong \& Co, New York. 
Stock, Eugene

1899 The History of the Church Missionary Society: Its Environment, Its Men, and Its Work, Vol. 3. Church Missionary Society, London, UK.

Stroomer, Harry

1987 A Comparative Study of Three Southern Oromo Dialects in Kenya: Phonology, Morphology and Vocabulary. Helmut Buske Verlag, Hamburg, Germany.

Sunseri, Thaddeus

1993 Slave Ransoming in German East Africa, 1885-1922. The International Journal of African Historical Studies 26(3):481-511.

Symonds, James, Timo Ylimaunu, Anna-Kaisa Salmi, Risto Nurmi,Titta Kallio-Seppä, Tiina Kuokkanen, Markku Kuorilehto, and Annemari Tranberg 2015 Time, Seasonality, and Trade: Swedish/Finnish-Sámi Interactions in Early Modern Lapland. Historical Archaeology 49(3):74-89.

Taylor, William Ernest 1891 African Aphorisms, or Saws from Swahili-Land. Society for Promoting Christian Knowledge, London, UK. Reprinted 1924 by The Sheldon Press, London, UK.

Thomson, Joseph 
1881. To the Central African Lakes and Back: The Narrative of the Royal Geographical Society's East Central African Expedition, 1878-1880, Vol. 1. Houghton, Mifflin, and Co, Boston, MA.

Vega, Bernardo

1979 Arqueologia de Los Cimarrones del Maniel del Bahoruco. Boletin del Museo del Hombre Dominicana 12:11-48.

Walz, Jonathan R. and Steven A. Brandt 2006 Toward an Archaeology of the Other African Diaspora: The Slave Trade and Dispersed Africans in the Western Indian Ocean. In African Re-genesis: Confronting Social Issues in the Diaspora, Jay B. Haviser, and Kevin C. MacDonald, editors, pp. 246-268. Left Coast Press, Walnut Creek, CA.

Weik, Terrance M.

1997 The Archaeology of Maroon Societies in the Americas: Resistance, Cultural Continuity, and Transformation in the African Diaspora. Historical Archaeology 31(2):81-92. 2002 A Historical Archaeology of the Black Seminole Maroons in Florida: Ethnogenesis and Culture Contact at Pilaklikaha. Doctoral dissertation, Department of Anthropology, University of Florida. University Microfilms International, Ann Arbor, MI. 2004 Archaeology of the African Diaspora in Latin America. Historical Archaeology 38(1):32 49. 
2005 Black Seminole Freedom Fighters on the Florida Frontier. In Unlocking the Past:

Celebrating Historical Archaeology in North America, Lu Ann De Cunzo and John H. Jameson Jr., editors, pp. 36-44. University Press of Florida, Gainesville.

2007 Allies, Enemies and Kin in the African-Seminole Communities of Florida: Archaeology at Pilaklikaha. In Archaeology of Atlantic Africa and the Africa Diaspora, Akinwumi Ogundiran and Toyin Falola, editors, pp. 311-331. Indiana University Press, Bloomington. 2012 The Archaeology of Anti-Slavery Resistance. University Press of Florida, Gainesville.

White, Cheryl

2009 Archaeological Investigations of Surinam Maroon Ancestral Communities. Caribbean Quarterly 55(2):65-88.

2010 Kumako: A Place of Convergence for Maroons and Amerindians in Suriname, SA. Antiquity 84(2):467-479.

2015. Taking a Closer Look at Retention, Rebellion, and Resistance: The Three R's of AfricanDiaspora Studies. In The Limits of Tyranny: Archaeological Perspectives on the Struggle against New World Slavery, James A. Delle, editor, pp. 241-262. The University of Tennessee Press, Knoxville.

Wilson, Brian C. and Mark W. Hauser

2016 Toward a South Asian Historical Archaeology. Historical Archaeology 50(4):7-21.

Woodson, Carter G. 
1920 The Relations of Negroes and Indians in Massachusetts. Journal of Negro History 5(1):45-

57.

Lydia Wilson Marshall

Department of Sociology and Anthropology

DePauw University

P.O. Box 37

Greencastle, IN 46135-0037

\section{FIGURE CAPTIONS}

FIGURE 1: The Swahili Coast (map by Beth Wilkerson, GIS Center, DePauw University, adapted from Continent Areas and Lakes data from Esri Data \& Maps 2013)

FIGURE 2: Kenya's 19th-century central coastal hinterland (map by Erin Minnick and Beth Wilkerson, GIS Center, DePauw University, adapted from Digital Chart of the World data, http://www.maproom.psu/dcw)

FIGURE 3: Carbonized wooden house post stubs, Structure 3, Koromio. The excavated unit is 2 meters by 2 meters, and the hole in the center of the unit is a previously excavated shovel-test pit (photo by author).

FIGURE 4: Reconstructed Swahili-style ceramic cooking lid, Structure 1, Koromio (photo by author).

\section{TABLES}

TABLE 1: Imported glass beads, Structure 1, Koromio. Those historical bead names whose application is more tenuous are marked by an asterisk.

\begin{tabular}{|llllllr|}
\hline $\begin{array}{c}\text { TYPE } \\
\#\end{array}$ & $\begin{array}{c}\text { MANUFACTURE } \\
\text { TECHNIQUE }\end{array}$ & $\begin{array}{c}\text { HISTORICAL } \\
\text { NAME }\end{array}$ & \multicolumn{1}{c}{ COLOR } & SHAPE & DIAPHANEITY & COUNT \\
\hline 1 & Drawn, Simple & Hafti & White & Short Barrel & Opaque & 23 \\
2 & Drawn, Simple & Dudio & White & Short Barrel & Translucent & 1 \\
3 & Drawn, Simple & Bubu & Black & Short Barrel & Opaque & 2 \\
4 & Drawn, Simple & Lakio & Brown & Short Barrel & Opaque & 1 \\
\hline
\end{tabular}




\begin{tabular}{|llllllr|}
\hline 5 & Drawn, Simple & Magio & Green & Short Barrel & Opaque & 4 \\
6 & Drawn, Simple & Wadiro* & Light Sky Blue & Short Barrel & Opaque & 5 \\
13 & Drawn, & Simsim & Scarlet & Short Barrel & Translucent & 4 \\
& Compound & & over White & & over Opaque & \\
16 & Wound & Sereketi & Dark Pink & Ellipsoid & Translucent & 1 \\
Total & & & & & 41 \\
\hline
\end{tabular}

TABLE 2: Imported glass beads, Structure 2, Koromio. Those historical bead names whose application is more tenuous are marked by an asterisk.

\begin{tabular}{|c|c|c|c|c|c|c|}
\hline $\begin{array}{c}\text { TYPE } \\
\#\end{array}$ & $\begin{array}{l}\text { MANUFACTURE } \\
\text { TECHNIQUE }\end{array}$ & $\begin{array}{l}\text { HISTORICAL } \\
\text { NAME }\end{array}$ & COLOR & SHAPE & DIAPHANEITY & COUNT \\
\hline 1 & Drawn, Simple & Hafti & White & Short Barrel & Opaque & 1 \\
\hline 6 & Drawn, Simple & Wadiro* & Light Sky Blue & Short Barrel & Opaque & 3 \\
\hline 7 & Drawn, Simple & Langiyo * & $\begin{array}{l}\text { Bright } \\
\text { Medium Blue }\end{array}$ & Short Barrel & Opaque & 11 \\
\hline 8 & Drawn, Simple & Kikete* & Bright Turquoise & Medium Barrel & Opaque & 1 \\
\hline 9 & Drawn, Simple & Sukoli & Orange & Medium Barrel & Opaque & 1 \\
\hline 10 & Drawn, Simple & - & Gray-Blue & Long Cylinder & Translucent & 1 \\
\hline 14 & $\begin{array}{l}\text { Drawn, } \\
\text { Compound }\end{array}$ & - & $\begin{array}{l}\text { Red } \\
\text { over Brown }\end{array}$ & Medium Cylinder & $\begin{array}{l}\text { Opaque } \\
\text { over Opaque }\end{array}$ & 1 \\
\hline 15 & $\begin{array}{l}\text { Drawn, } \\
\text { Compound }\end{array}$ & - & $\begin{array}{l}\text { Turquoise } \\
\text { over White }\end{array}$ & Medium Barrel & $\begin{array}{l}\text { Opaque } \\
\text { over opaque }\end{array}$ & 2 \\
\hline 17 & Wound & Sungomaji & White & Ellipsoid & Opaque & 2 \\
\hline 19 & Wound & Nílí* & Green & Ellipsoid & Translucent & 2 \\
\hline 20 & Wound & - & White & Spheroid & Opaque & 2 \\
\hline 21 & Press-Molded & - & Green & Short Barrel & Translucent & 1 \\
\hline Total & & & & & & 28 \\
\hline
\end{tabular}

TABLE 3: Imported glass beads, Structure 3, Koromio.

\begin{tabular}{|llllllr|}
\hline $\begin{array}{l}\text { TYPE } \\
\#\end{array}$ & $\begin{array}{l}\text { MANUFACTURE } \\
\text { TECHNIQUE }\end{array}$ & $\begin{array}{l}\text { HISTORICAL } \\
\text { NAME }\end{array}$ & COLOR & SHAPE & DIAPHANEITY & COUNT \\
\hline 1 & Drawn, Simple & Hafti & White & Short Barrel & Opaque & \\
13 & Drawn, & Simsim & $\begin{array}{l}\text { Scarlet } \\
\text { over White }\end{array}$ & Short Barrel & $\begin{array}{l}\text { Translucent } \\
\text { over Opaque }\end{array}$ & 1 \\
& Compound & Sungomaji & White & Ellipsoid & Opaque & 1 \\
17 & Wound & Sungomaji & $\begin{array}{l}\text { Bright } \\
\text { Medium Blue }\end{array}$ & Ellipsoid & Opaque & 2 \\
& Wound & & & & 6 \\
Total & & & & & & \\
\hline
\end{tabular}




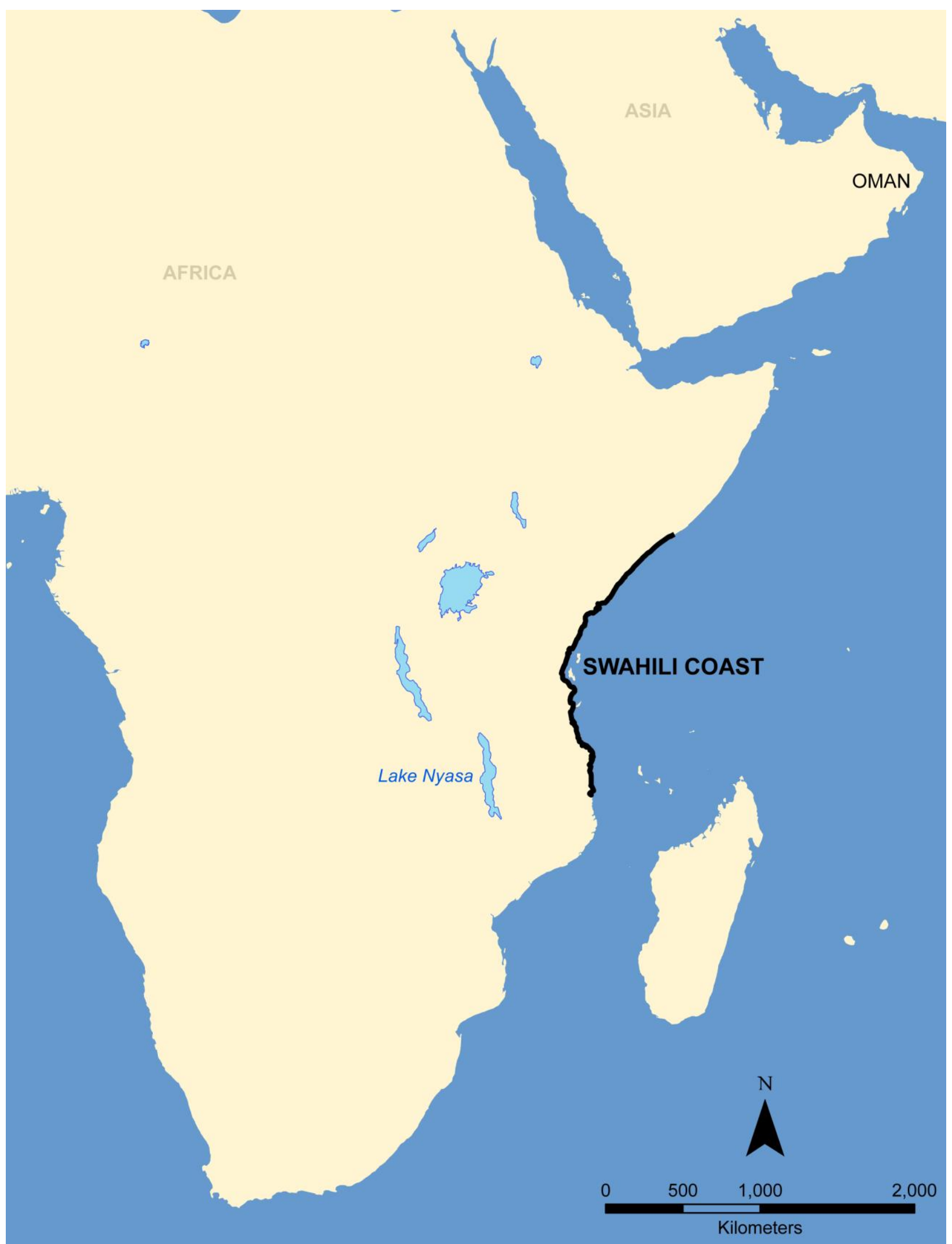

Figure 1 


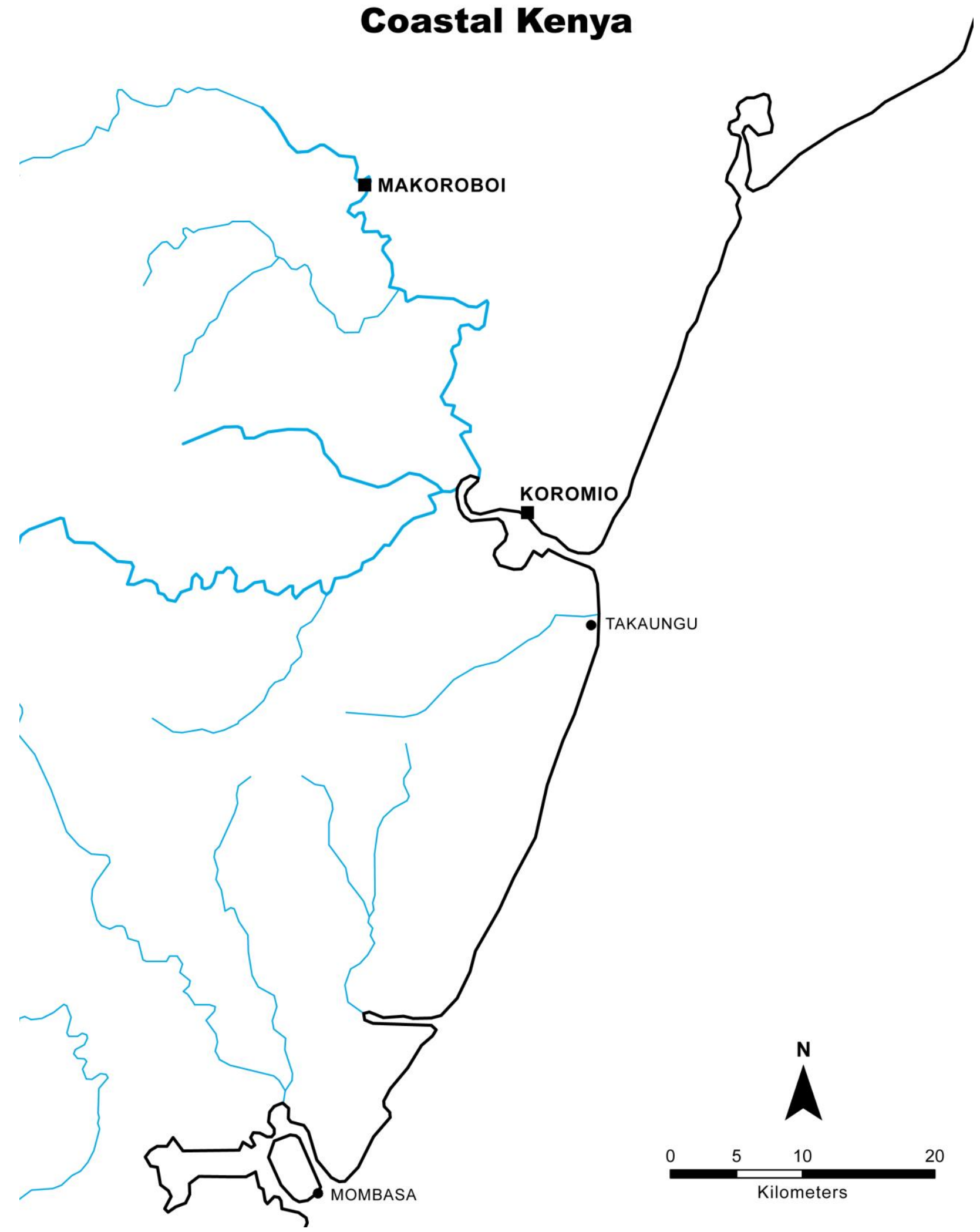

Figure 2 


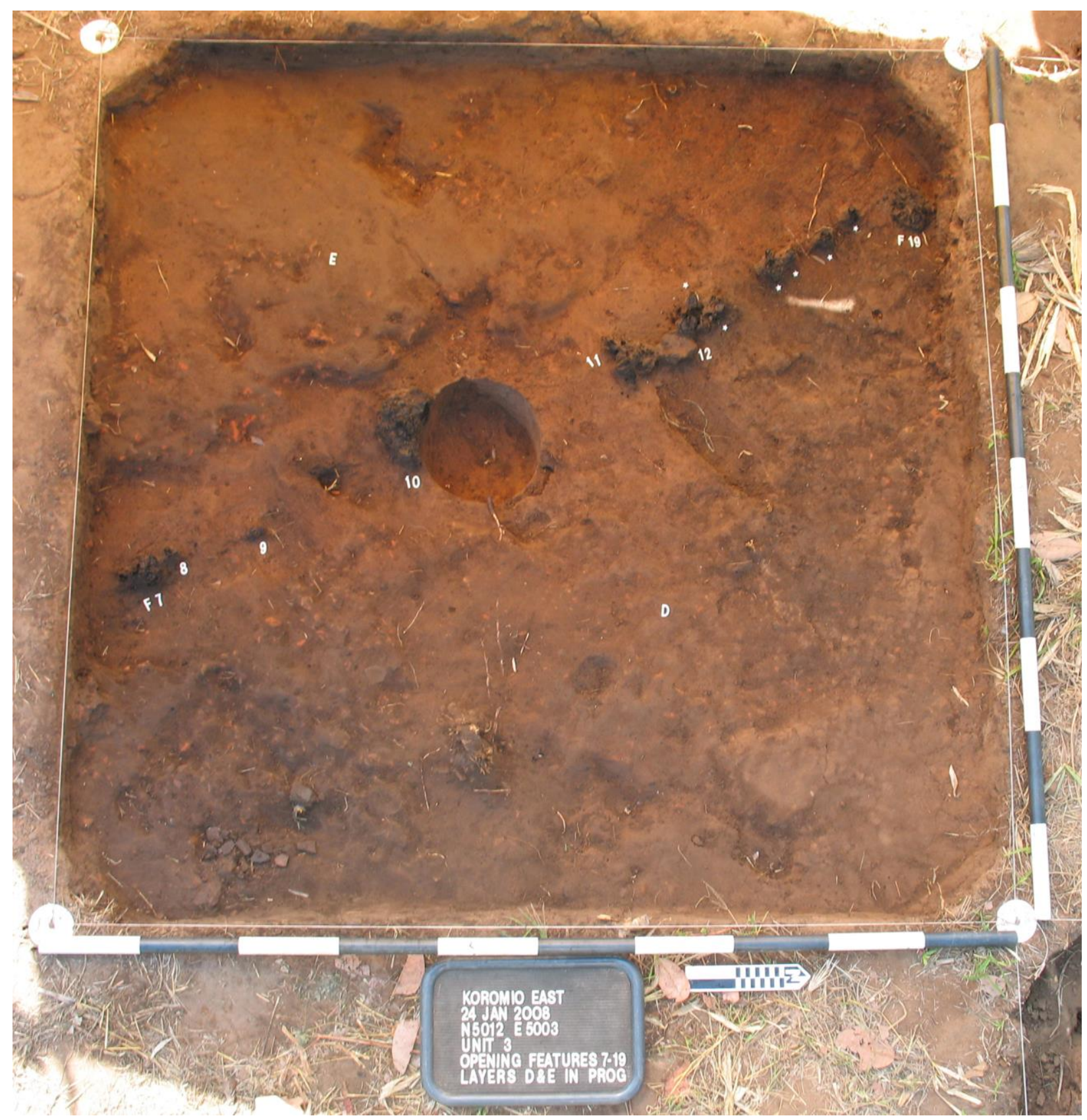

Figure 3 


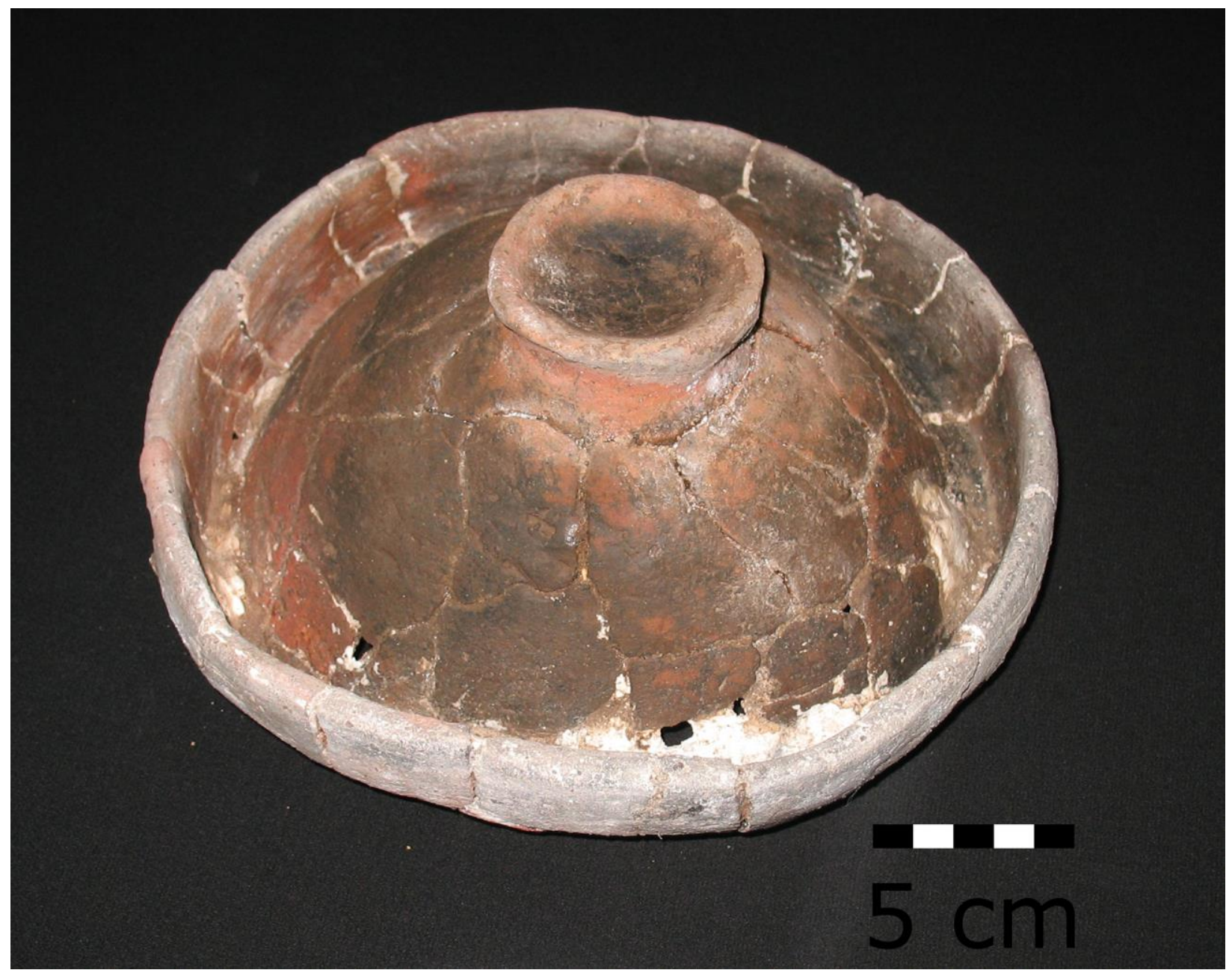

Figure 4 